NBER WORKING PAPER SERIES

WHAT DOES THE BUNDESBANK TARGET?

Ben S. Bernanke

Ilian Mihov

Working Paper 5764

NATIONAL BUREAU OF ECONOMIC RESEARCH

1050 Massachusetts Avenue

Cambridge, MA 02138

September 1996

The authors thank the discussants, Lawrence Christiano and Jurgen von Hagen, as well as the editor and anonymous referees, for useful comments. Don Redl's excellent assistance and financial support from the National Science Foundation are both gratefully acknowledged. This paper is part of NBER's research programs in Economic Fluctuations and Growth, and Monetary Economics. Any opinions expressed are those of the authors and not those of the National Bureau of Economic Research.

(C) 1996 by Ben S. Bernanke and Ilian Mihov. All rights reserved. Short sections of text, not to exceed two paragraphs, may be quoted without explicit permission provided that full credit, including $(\mathcal{C}$ notice, is given to the source. 


\title{
WHAT DOES THE BUNDESBANK TARGET?
}

\begin{abstract}
Although its primary ultimate objective is price stability, the Bundesbank has drawn a distinction between its money-focus strategy and the inflation targeting approach recently adopted by a number of central banks. We show that, holding constant the current forecast of inflation, German monetary policy responds very little to changes in forecasted money growth; we conclude that the Bundesbank is much better described as an inflation targeter than as a money targeter. An additional contribution of the paper is to apply the structural VAR methods of Bernanke and Mihov (1995) to determine the optimal indicator of German monetary policy: We find that the Lombard rate has historically been a good policy indicator, although the use of the call rate as an indicator cannot be statistically rejected.
\end{abstract}

Ben S. Bernanke

Woodrow Wilson School

Princeton University

Princeton, NJ 08544

and NBER

bernanke@wws.princeton.edu
Ilian Mihov

INSEAD

Boulevard de Constance

77305 Fontainebleau

FRANCE 


\section{Introduction}

In the past few years a significant number of central banks-including those of Canada, New Zealand, Britain, and Sweden--have adopted some form of "inflation targeting" as a framework for monetary policy. In an inflation targeting regime, the central bank and/or the government announce explicit goals for the inflation rate, usually at several horizons. Although attainment of the inflation target does not necessarily exclude other objectives, such as short-run stabilization of output or exchange rates, meeting the inflation target at medium and long horizons is treated as the overriding goal of policy. ${ }^{1}$

As a strategy for conducting monetary policy, inflation targeting has some appealing features, including (perhaps) greater ease in explaining policy objectives to the public and the avoidance of the "velocity instability" problem that can arise when policy relies heavily on a single intermediate target. On the other hand, potentially serious problems with inflation targeting include the difficulty of making accurate inflation forecasts and reduced accountability arising from the substantial lags between policy actions and inflation outcomes.

Because inflation targeting bears great promise but also significant risk for its adopters, it would be most useful to know how this strategy has worked in practice. Unfortunately, the explicit adoptions of inflation targets by industrial-country central banks have all occurred within the last five years or so, so that the relevant experiences are short. A possible exception to this statement--which motivates this paper--is the case of Germany. ${ }^{2}$ Since the end of 1974 , the Bundesbank has conducted monetary policy in a framework that is

\footnotetext{
${ }^{1}$ Eor excellent discussions of comparative inflation targeting experience, see Goodhart and Vinals (1994), Leiderman and Svensson (1995), and Haldane (1995).

${ }^{2}$ Switzerland also follows a German-style strategy, although it has emphasized narrower money aggregates in its intermediate targeting.
} 
officially designated as money targeting--and in which money growth rates certainly play an important role--but which also appears to have significant elements of inflation targeting. As von Hagen (1995) and others have emphasized, and as we discuss further in section 3 , from the inception of the current regime the Bundesbank has used a projection of inflation for the next year as the main input to its derivation of its money growth target. Except for a small blip in 1980, this inflation projection has been low and steadily declining; since 1986 it has been constant at 28 per year, the level the Bundesbank deems consistent with "price stability". Thus it might be argued that inflation goals, rather than money growth targets, are the driving force behind German monetary policy. This conclusion would not be grossly inconsistent with the German public's perception of the Bundesbank's behavior, nor with the Bundesbank's 1957 charter, which designates the safe-guarding of the currency as the bank's prime responsibility. On the other hand, as we also document in section 3, the Bundesbank itself draws a strong distinction between inflation targeting, as adopted by the U.K. and others, and its own money-focused approach; and it argues that the latter, if feasible, is the superior strategy.

Is the Bundesbank, then, "really" an inflation-targeter or not? That is the question we try to answer in this paper. To make the question more precise, we consider the following thought-experiment: Suppose that the Bundesbank were to observe money growth coming in higher than expected, but (because of offsetting factors) its forecast of inflation did not change. Then would the Bundesbank tighten policy? If not, we would say that for most intents and purposes the Bundesbank is an inflation targeter. If it did tighten, then we would classify it as a money targeter (albeit one with important inflation objectives). Resolving this question would help us to decide whether to treat the Bundesbank's success in controlling inflation as an argument for or 
against the inflation-targeting approach, and perhaps allow us to draw useful lessons from the Bundesbank's experience. A more concrete consideration is the following: Currently, the designers of the embryonic European Central Bank are debating the type of monetary policy strategy the ECB should use, the two leading candidates being inflationtargeting and money-targeting. There appears to be some political pressure from Germany for the ECB to adopt money-targeting, presumably in order to reassure the German public that the ECB's policies will be very similar to those of the Bundesbank. We are concerned that moneytargeting might be a poor choice for the ECB, on the grounds that velocity is likely to be very unstable in the early stages of monetary union. If it could be demonstrated that the Bundesbank has really been inflation-targeting (with money targets happening to be a convenient instrument, given the particular characteristics of the German financial system), this contentious issue might be resolved.

In order to answer the question of how the Bundesbank has responded to changes in money growth, we obviously need some indicator of German monetary policy other than money growth itself; we also need empirical estimates of how changes in this indicator will affect the evolution of prices and other key variables. These issues are addressed in Section 2. Like a number of recent authors, we study German monetary policy and its impacts in the context of a vector autoregression (VAR)based approach. Unlike most recent work, however, we do not simply assume that some particular variable is the appropriate measure of policy; instead, we follow the methodology advocated by Bernanke and Mihov (1995) and derive the policy indicator from structural VAR estimates of the Bundesbank's operating procedures. We find that, as an indicator of German monetary policy during the 1975-1990 period, the Lombard rate is at least marginally to be preferred to the call rate, 
which is the indicator of policy that has been used in most previous studies. This finding may be of independent interest.

Section 3 uses the VAR framework to address the question posed by our paper's title. Specifically, we ask whether the expected evolution of the money stock affects the Bundesbank's setting of the Lombard rate, given the forecast of inflation (as well as other potential objective variables). Our results generally support the inflation-targeting view of the Bundesbank. In particular, although money growth forecasts retain predictive power for the Lombard rate (in the sense of Grangercausality) even when several objectives of policy are allowed for, at medium-term and longer horizons forecasted inflation explains a much greater share of the variance of German monetary policy than does forecasted money growth lor, for that matter, than forecasted changes in output or the value of the Deutschemark).

\section{Identifying monetary policy in Germany}

In order to answer the question of how the Bundesbank responds to changes in forecasts of inflation, money growth, or other variables, our first task is to identify an appropriate indicator of Bundesbank policy. To do this, in this section we employ the VAR-based approach suggested by Bernanke and Mihov (1995). This approach is similar to the methodology employed by Bernanke and Blinder (1992), Christiano and Eichenbaum (1992), Sims (1992), Christiano, Eichenbaum, and Evans (1994), Strongin (1995), and many other recent papers, in that the effects of monetary policy in the economy are identified with the dynamic responses of variables in a VAR to innovations to an indicator of monetary policy. The Bernanke-Mihov approach differs from others, however, in that it uses estimates of the central bank's operating procedure to identify the policy indicator, rather than picking the 
indicator on purely a priori grounds. Section 2.1 describes this methodology; those familiar with it may skip this subsection without loss of continuity. Section 2.2 discusses the evolution of Bundesbank operating procedures and proposes a structural VAR model of those procedures. Section 2.3 presents results, focusing on the comparison between the call rate and the Lombard rate as candidate indicators of German monetary policy.

2.1 Methodology. To derive the Bernanke-Mihov approach formally, we follow them in supposing that the economy is described by the linear structural model given in equations $(2.1)-(2.2)$ :

$$
\begin{aligned}
& \mathbf{Y}_{t}=\sum_{i=0}^{k} \mathbf{B}_{i} \mathbf{Y}_{t-i}+\sum_{i=0}^{k} \mathbf{C}_{i} \mathbf{P}_{t-i}+A^{y} \mathbf{v}_{t}^{y} \\
& \mathbf{P}_{t}=\sum_{i=0}^{k} \mathbf{D}_{i} \mathbf{Y}_{t-i}+\sum_{i=0}^{k} \mathbf{G}_{i} \mathbf{P}_{t-i}+A^{p} \mathbf{v}_{t}^{p}
\end{aligned}
$$

where boldface variables denote vectors or matrices. The distinction between variables that are elements of $\mathbf{Y}$ and those that are element of P will be explained momentarily.

Equations (2.1)-(2.2) may be viewed as a standard Cowles-type system of simultaneous equations, in which each variable (i.e., any component of $\mathbf{Y}$ or $\mathbf{P}$ ) is allowed to depend on current or lagged values of any variable in the system. ${ }^{3}$ In eqs. (2.1)-(2.2) the $\mathbf{v}$ 's are mutually uncorrelated "structural" or "primitive" disturbances; as in Bernanke (1986), these structural disturbances are premultiplied by general matrices $\mathbf{A}$, which permit any disturbance in the $\mathbf{Y}$ block to enter into any equation in that block, and similarly for the $\mathbf{P}$ block.

\footnotetext{
${ }^{3}$ Expectational variables could be accommodated in this framework by replacing expected future values with linear projections on current and past values of any variable in the system. Consistent with the real business cycle framework, one could also interpret some of the equations in the system as decision rules relating current choice variables to variables describing the current state of the economy.
} 
Thus no restriction is placed on the covariance matrices of composite error terms within a block. The only restriction imposed by this way of writing the error terms is that the error terms in the two blocks are uncorrelated. Since we will always allow contemporaneous elements of $\mathbf{Y}$ to enter the $\mathbf{P}$ block in an unrestricted manner, this assumption is not particularly stringent.

Equations (2.1) and (2.2) partition the variables under consideration into two groups, $\mathbf{Y}$ and $\mathbf{P}$, which we refer to as "nonpolicy" and "policy" variables, respectively. The set of policy variables includes variables that are potentially useful as direct indicators of the stance of monetary policy, e.g., short-term interest rates and reserves measures. Non-policy variables include other economic variables, such as output and inflation, whose responses to monetary policy shocks we would like to identify.

With respect to the identification of monetary policy shocks and their effects on the economy, there are two cases of interest. The first possibility is that there exists a single variable which is known a priori to contain the relevant information about the stance of monetary policy; i.e., $\mathbf{P}$ is a scalar, say $\boldsymbol{p}$, rather than a vector. In the scalar case eq. (2.2) can be rewritten as:

$$
p_{t}=\sum_{i=0}^{k} \mathrm{D}_{i} \mathbf{Y}_{t-i}+\sum_{i=1}^{k} g_{i} p_{t-i}+v_{t}^{p}
$$

Most of the recent VAR literature has employed a scalar monetary policy indicator (e.g., the federal funds rate in the United states). In European applications, all studies of which we are aware have used a short-term market interest rate, such as the call rate or a government bill rate, as the policy indicator (see, e.g., Sims, 1992; Gerlach and Smets, 1995; Clarida and Gertler, 1995; Tsatsaronis, 1995; Barran et al., 1996). In the case of a scalar policy indicator, as is by now well 
known, identification of the effects of policy shocks on the non-policy variables can be achieved by means of a simple "timing" assumption. For example, as is most common in the literature, suppose we are willing to assume that policy innovations do not affect non-policy variables within the same period (i.e., the elements of the vector $\mathbf{C}_{0}$ in eq. (2.1) are all zero). Under this assumption the system (2.1)-(2.2) can be written in VAR format by projecting the vector of dependent variables on $k$ lags of itself. Estimation of the resulting system by standard VAR methods, followed by a Choleski decomposition of the covariance matrix (with the policy variable ordered last) yields an estimated series for the exogenous policy shock $v^{p}$. Impulse response functions for all variables with respect to the policy shock can then be calculated, and can be interpreted as the true structural responses to policy innovations.

It is worth emphasizing the substantial advantage of this approach, relative to traditional Cowles methods and more completelyidentified VAR analyses, that responses to policy can be measured without identifying assumptions other than the timing assumption. However, this methodology does require that one accept the idea that there are exogenous shocks to monetary policy, uncorrelated with the current state of the economy. The appendix to this paper illustrates how such shocks could arise from plausible sources, such as imperfect current information on the part of the central bank or shifts in central bank preferences.

The second case of interest occurs when there is no unique, scalar indicator of policy, i.e., $\mathbf{P}$ has two or more elements. This case in turn is relevant in at least two distinct situations. First, central banks sometimes use hybrid operating procedures--a combination of interest-rate targeting and reserves-targeting, for example. In that scenario, both interest rates and reserves will contain information 
about monetary policy (but will also be affected by shocks to the demand for reserves and other factors). Second, although it may be that a scalar measure is ultimately appropriate, the econometrician may be uncertain about which variable or set of variables is the best measure of monetary policy, and would like to compare alternative possibilities statistically. As we demonstrate in the application below, this situation is also accommodated by a non-scalar $\mathbf{P}$, taken in this case to be a list of the candidate indicators.

Identification of policy shocks in the case in which $\mathbf{P}$ has multiple elements is analogous to the scalar case. Suppose that one element of the set of shocks $\mathbf{v}^{p}$ affecting $\mathbf{P}$ in eq. (2.2) is a shock to monetary policy, denoted $\boldsymbol{v}^{\prime}$. To identify $\boldsymbol{v}^{\prime}$, and the responses of other variables in the system to that shock, we make a timing assumption like the one used in the scalar case; i.e., we assume that innovations to variables in the policy block do not affect variables in the non-policy block within the period, or $C_{0}=0$. Now suppose that we write the system (2.1)-(2.2) in standard VAR form (with only lagged variables on the right-hand side, and with the $\mathbf{Y}$ block prior to the $\mathbf{P}$ block). Define $\mathbf{u}_{t}^{y}$ to be the VAR residuals corresponding to the $\mathbf{Y}$ block and $\mathbf{u}_{t}^{p}$ to be the residuals corresponding to the $\mathbf{P}$ block, orthogonalized with respect to $\mathbf{u}_{t}^{y}$. Then Bernanke and Mihov (1995) show that

$$
\text { (2.4) } \quad \mathbf{u}_{t}^{p}=\left(I-G_{0}\right)^{-1} A^{p} \mathbf{v}_{t}^{p}
$$

where the right-side parameters and disturbances are as defined in the structural equation (2.2). Alternatively, dropping subscripts and superscripts, we can rewrite eq. (2.4) as:

$$
\text { (2.5) } \mathbf{u}=\mathbf{G u}+\mathbf{A v}
$$


Equation (2.5) is a structural VAR (SVAR) system, which relates observable VAR-based residuals $\mathbf{u}$ to unobserved structural shocks $\mathbf{v}$, one of which is the policy shock $\boldsymbol{v}^{3}$. This system can be identified and estimated by conventional methods, allowing recovery of the structural shocks, including $\boldsymbol{v}^{s}$. The policy shock $\boldsymbol{v}^{\text {s }}$ is analogous to the innovation to the scalar policy indicator in studies such as Bernanke and Blinder (1992), Sims (1992), and Christiano, Eichenbaum, and Evans (1994). As in the scalar case, the structural responses of all variables in the system to a policy shock can be measured by the associated impulse response functions. In the next subsection we apply this method to an analysis of the Bundesbank's operating procedure, then use our estimates to develop an indicator of German monetary policy.

\subsection{Instruments and indicators of Bundesbank policy. Bernanke} and Mihov (1995) emphasize that, in order to develop a reliable indicator of monetary policy, it is important to understand the central bank's operating procedure and instruments. In general, using a variable that the central bank allows to respond to reserves-market shocks as a policy indicator will lead to incorrect inferences about the effects of policy changes on the economy. (The appendix illustrates this point by means of an algebraic example in which the central bank may target either money or interest rates.) Thus, as a necessary prior step to finding the appropriate indicator for German monetary policy, we here briefly discuss and model the Bundesbank's operating procedure." Prior VAR studies which use the call rate or other short-term market interest rate as a measure of German monetary policy are, at least to some extent, relying on the analogy to the U.S. federal funds

${ }^{4}$ Good descriptions of Bundesbank procedures may be found in Trehan (1988); Kahn and Jacobson (1989); Kneeshaw and van den Bergh (1989); von Hagen (1989); Batten et al. (1990); Kasman (1992); von Hagen and Neumann (1993); Clarida and Gertler (1995); and Deutsche Bundesbank (1995). 
rate. Although Bundesbank operations have become increasingly similar to those of the Fed over time, however, historically there are some important differences. The Fed has used open-market operations in government securities as its principal tool of reserves management for many decades; relatively speaking, the Fed's other tools--its ability to set commercial banks' reserve requirements and to make loans through the discount window--have played a minor role in monetary policy. And, since the maturation of the federal funds market in the mid-1960s, except during the 1979-1983 "Volcker experiment", the Fed has treated the federal funds rate as its primary short-run target. Thus, at the operational level, the differences in Fed policy-making between the 1970 s and the 1990 s are not large.

In contrast, the Bundesbank has seen considerably more evolution in its instruments of policy. Prior to about 1980, the German central bank did not make frequent use of open market operations. Instead, in the earlier period it implemented desired changes in the stance of monetary policy, for the most part, in one of three ways:

First, it made relatively frequent changes in reserve requirements (which are fairly high in Germany, compared to other countries). Some indication of the active use of reserve requirements is given by Figure 1, which shows the ratio of current required reserves to required reserves at 1974 legal ratios. (The denominator is obtained by subtracting currency in circulation from central bank money at 1974 ratios.) Since (given the composition of deposits) the former but not the latter varies with changes in reserve requirements, this ratio is a rough measure of how requirements have changed. Also shown in the figure are dates of official changes in requirements (denoted by vertical lines). Note the relatively frequent use of this instrument prior to about 1981 . 
Second, in the earlier period the Bundesbank eased (tightened) policy by increasing (reducing) discount-window borrowing quotas for banks. Since the discount rate in Germany is below the market rate of interest, and moral suasion is not used (in the manner of the Fed) to reduce discount-window borrowing, banks usually borrow up to their quota. Thus, changes in quotas translated directly into changes in the quantity of reserves available to the banking system.

Finally, the Bundesbank could affect the quantity of loans through its second borrowing facility (Lombard loans) by changing the rate charged banks for those loans (the Lombard rate). In the earlier period the Lombard rate was typically held below the market rate for reserves (the call rate), but above the discount rate, and thus functioned analogously to the U.S. discount rate.

For our purposes, a key aspect of Bundesbank operating procedures prior to about 1980 was their relative lack of flexibility. All three tools--reserve requirements, discount-window quotas, and the Lombard rate--could be, or at least were, changed only on a discrete rather than continuous basis. Thus the Bundesbank lacked the ability, enjoyed by the Fed, of finely targeting market interest rates. However, over the last fifteen years that situation has changed, for two principal reasons. First, the Bundesbank has begun dealing in repurchase agreements (repos) with banks. Repos provide a means by which the Bundesbank can make short-term loans to the banking system. Second, aided by a deepening of securities markets, the Bundesbank has made increasing use of U.S.-style open-market operations. These two developments have greatly increased the Bundesbank's ability to "finetune" movements in market interest rates, such as the call rate. Indeed, in a short-term operational sense, the Bundesbank is able now to target the call rate or other rates (such as the repo rate) in very much the way that the Fed pegs the federal funds rate. 
What implications do the changes in Bundesbank instruments and operating procedures have for the choice of a monetary indicator for Germany? A tentative conclusion is that it may be somewhat risky to use the call rate (or other short-term market rate) as one's indicator of monetary policy, at least prior to 1980 or so. Because the Bundesbank lacked the tools to target open-market interest rates precisely, it seems possible that short-term innovations in market rates might have reflected non-policy factors in the economy, such as shifts in the demand for reserves, as well as policy innovations. If shocks to the call rate reflect non-policy influences, then measured impulse responses to call rate innovations are no longer "clean" estimates of the effects of monetary policy shocks on the economy.

A bit of indirect evidence on this issue is the persistence of the "price puzzle" for Germany. For example, Sims (1992) found (both for Germany and other countries) that the price level rises following a positive innovation to the call rate, despite the presumption that an increase in the call rate represents a tightening of monetary policy. Sims finds that this perverse response of prices persists for Germany even when commodity prices and the exchange rate are included in the system to control for anticipated future inflation. Sims's sample begins in 1961, and thus includes a lengthy period prior to the introduction of repos and the expanded use of open-market operations. However, Clarida and Gertler (1995) estimate VARs with German data beginning in the mid-1970s and also find a positive response of prices to call rate innovations. We present further evidence below.

These considerations suggested to us that it might be worthwhile to make a closer empirical examination of the Bundesbank's operating procedures. We found that, with some conceptual re-definitions, we could apply the model of the reserves market proposed by Bernanke and 
Mihov (1995) for the U.S. to the German case. Our adaptation of their model, written in innovation form, is as follows:

(2.7) Total reserves demand: $\quad u_{T_{R}}=-\infty u_{C R}+v^{d}$

(2.8) Lombard loans demand: $\quad u_{L L}=\beta\left(u_{C R}-u_{L A}\right)+v^{b}$

(2.9) Nonborrowed reserves supply: $u_{N B R}=\phi^{d} v^{d}+\phi^{b} v^{b}+\phi^{s} v^{s}+v^{n}$

(2.10) Lombard rate: $\quad u_{L R}=\gamma^{d} v^{d}+\gamma^{n} v^{n}+\gamma^{b} v^{b}+v^{s}$

where $T R$ is total reserves, $L L$ is Lombard loans, $N B R$ is nonborrowed reserves, $L R$ is the Lombard rate, and $C R$ is the call rate.

Equation (2.7) relates the innovation in the demand for bank reserves to the innovation in the call rate (analogous to the federal funds rate in the U.S.) and an autonomous shock to reserves demand. For simplicity, we abstract here from the Bundesbank's use of reserve requirements as a policy tool: Hence we measure total bank reserves as required reserves at 1974 ratios (equal to central bank money at 1974 ratios less currency in circulation), plus excess reserves. This adjustment, albeit somewhat crude, does eliminate the large jumps in reserves associated with changes in the legal requirements.

Equation (2.8) assumes that, in innovations form, the demand for Lombard loans (analogous to discount-window borrowing in the U.S.) depends on the spread between the call rate and the Lombard rate (analogous to the U.S. funds rate-discount rate spread) and a shock to desired Lombard borrowing. A difference between Lombard borrowing and U.S. discount-window borrowing is that--as noted above--since 1985 the Lombard rate has been at or above the call rate, while the U.S. discount rate is virtually always below the federal funds rate. One would expect Lombard loans to be very low when the rate charged on those loans 
exceeds the open-market borrowing rate, and that is indeed the case.

However, Lombard loans have not been zero during the past decade by any

means, presumably because some banks have emergency borrowing needs or have imperfect access to the call market. Since the spread between the call rate and the Lombard rate is still a measure of the opportunity cost of using the Lombard window, we would expect eq, (2.8) to apply during the recent period, although one should be wary of possible breaks in the structural parameters (which we will always allow for).5

Equations (2.9) and (2.10) describe the behavior of the Bundesbank. Equation (2.9) is the supply of nonborrowed reserves, defined as total reserves less Lombard loans. Thus, we include borrowings at the discount window as part of "nonborrowed" reserves; this seems to be the right simplification, since--as discussed above-discount-window loans are inframarginal and could just as well be supplied via open-market operations or other methods. Equation (2.9) allows for the possibility that the Bundesbank can observe and offset shocks to the bank reserves market--which would be necessary to target the call rate on a month-to-month basis, for example. There is also an autonomous shock to the supply of nonborrowed reserves, $\boldsymbol{v}^{n}$. Equation (2.10) describes the Bundesbank's setting of the Lombard rate; again, this equation is (so far) unrestricted, allowing both for the Bundesbank to use the Lombard rate to offset other shocks in the reserves market, and for autonomous innovations to the Lombard rate, $v^{s}$.

\footnotetext{
${ }^{5}$ As our discussant van Hagen pointed out, on a few occasions during our sample period the Bundesbank imposed additional restrictions on Lombard lending: Between September 1979 and March 1980, limits on Lombard lending equal to $15 \%$ of the standard rediscount quota were imposed. Between February 1981 and May 1982, the Bundesbank granted "special" Lombard loans at 38 above the regular Lombard rate, with provisions for recall or changes in the rate at short notice; the regular Lombard window was closed. We do not account for these periods in our analysis, which may cause us to understate the tightness of monetary policy during those episodes. Special Lombard loans have been discontinued since 1982 .
} 
Using the identity $u_{T R}=u_{N B R}+u_{L L}$, we can write the solution of this model in the form of eq. $(2.4)$, where $\mathbf{u}^{\prime}=\left|\begin{array}{llll}u_{T R} & u_{N B R} & u_{C R} & u_{L R}\end{array}\right|, v^{\prime}=\left|\begin{array}{llll}v^{d} & v^{b} & v^{n} & v^{s}\end{array}\right|$, and

$$
(\mathbf{I}-\mathbf{G})^{-1} \mathbf{A}=\left|\begin{array}{cccc}
1-\frac{\alpha\left(1-\phi^{d}+\beta \gamma^{d}\right)}{\alpha+\beta} & \frac{\alpha\left(1+\phi^{b}-\beta \gamma^{b}\right)}{\alpha+\beta} & \frac{\alpha\left(1-\beta \gamma^{n}\right)}{\alpha+\beta} & \frac{\alpha\left(\phi^{s}-\beta\right)}{\alpha+\beta} \\
\phi^{d} & \phi^{b} & 1 & \phi^{s} \\
\frac{1-\phi^{d}+\beta \gamma^{d}}{\alpha+\beta} & -\frac{1+\phi^{b}-\beta \gamma^{b}}{\alpha+\beta} & -\frac{1-\beta \gamma^{n}}{\alpha+\beta} & -\frac{\phi^{s}-\beta}{\alpha+\beta} \\
\gamma^{d} & \gamma^{b} & \gamma^{n} & 1
\end{array}\right|
$$

This model has twelve unknown parameters (including four shock variances) to be estimated from ten residual variances and covariances; thus further identifying restrictions are necessary. Bernanke and Mihov (1995) used two strategies for achieving identification: First, they showed that some simple operating procedures, such as federal funds rate-targeting, implied overidentification of this model. Thus the combination of the model and the proposed operating procedure could be tested in the data, by applying standard tests of overidentifying restrictions. Second, as an alternative, they made enough additional assumptions to just-identify the model, estimates of which implied an "optimal" policy indicator (in general, a weighted average of alternative simple indicators).

Here we restrict ourselves to the first strategy and consider three simple alternative characterizations of Bundesbank operating procedures: call-rate smoothing, nonborrowed reserves targeting (where, again, "nonborrowed reserves" is defined as total reserves less Lombard loans), and smoothing of the Lombard rate (i.e., insulation of the Lombard rate from reserves-market shocks). Each of these alternatives can be used to impose additional identifying restrictions on the model. 
For the call-rate model, we impose

$$
1-\phi^{d}+\beta \gamma^{d}=0,1+\phi^{b}-\beta \gamma^{b}=0, \phi^{s}=0
$$

The first two restrictions imply that the call rate does not respond to (i.e., the Bundesbank offsets) reserves demand and Lombard borrowing shocks (cf. the third row of the matrix $(\mathbf{I}-\mathbf{G})^{-1} \mathbf{A}$ above). The third restriction says that the call rate is allowed to passively adjust (i.e., no changes are made in nonborrowed reserves) to innovations in the Lombard rate. This seemed to be the right assumption; otherwise, we would have to assume that changes in the Lombard rate are "sterilized" and thus have no effect on open-market rates. However, the alternative assumption, that the call rate is insulated from Lombard rate shocks as well as reserves and borrowings shocks $\left(\phi^{s}=\beta\right)$, led to similar empirical results.

For nonborrowed-reserves targeting (which seems reasonable to consider for the Bundesbank, given its putative close attention to money growth targets), we impose the restrictions

$$
\phi^{d}=0, \phi^{b}=0, \phi^{\prime}=0
$$

i.e., nonborrowed reserves depend only on their own autonomous shocks and are not systematically adjusted in response to contemporaneous shocks in the bank reserves market.

Finally, for Lombard-rate targeting, we impose

$$
\gamma^{d}=0, \gamma^{b}=0, \gamma^{n}=0
$$

or that the Lombard rate is independent of contemporaneous reservesmarket shocks. The assumptions associated with all three procedures are identical to those used by Bernanke and Mihov (1995) in their model including the discount rate. Note that in this setup there are two 
structural shocks that can be interpreted as "policy shocks": the reserves innovation $v^{n}$ (emphasized by the call rate and nonborrowed reserves models), and the Lombard rate innovation $v^{s}$ (emphasized by the Lombard rate model).

Each of these alternative characterizations of Bundesbank operating procedures imposes three additional restrictions on, and thus over-identifies, the general model. In the next sub-section we report parameter estimates and statistical comparisons for these three models.

2.3 Estimates of the Bundesbank's operating procedure. To implement the above procedure we need to specify the "nonpolicy" variables $\mathbf{Y}$ and the "policy variables" $\mathbf{P}$. In all VARs discussed in this section we use three nonpolicy variables: the index of German industrial production, the German CPI, and the Dow-Jones index of commodity prices (not specific to Germany). Industrial production and the CPI are probably the best available monthly indicators of output and inflation. The index of commodity prices is included to account for supply shocks and to capture information about future inflation that the Bundesbank might have when choosing its policy stance (see Sims, 1992, for a discussion). Policy variables include total bank reserves (defined as central bank money at 1974 reserve ratios, minus currency in circulation, plus excess reserves); "nonborrowed" reserves (total reserves less Lombard loans); the call rate; and the Lombard rate. In some of the preliminary results described below the Lombard rate is dropped from the VAR. All data are from Datastream, except the commodity price index, which is from CITIBASE. Interest rates are included in the VARs in levels, other variables in log-levels. ${ }^{6}$

\footnotetext{
We include the output, price, and reserves measures in levels despite their nonstationarity, as has become standard practice in VAR studies. The levels specification will yield consistent estimates whether cointegration exists or not, whereas a differences specification is inconsistent if some variables are cointegrated. clarida and Gertler
} 
Data were available from January 1969 through 1995, except that reserves data are missing during the transition period July-December 1990. In what follows we always end the sample period in June 1990, to avoid dealing with the unification period and its aftermath (which obviously raised special problems for the Bundesbank).

We applied a variety of lag-length and stability tests to the reduced-from parameters of the seven-variable VAR. The likelihood ratio test with a modified multiplier suggested by sims (1980) rejected truncation at less than twelve lags; hence, for all the principal results reported below we use twelve-lag VARs. (For a few shortersample results reported in Table 1 , we needed to use fewer lags to conserve degrees of freedom. Additional tests confirmed that a lag structure of $(1,2,3,4,9,12)$ was adequate to capture the main dynamics of the data.) To test stability of the reduced-form parameters (with unknown break point) we used an LM-type test, testing simultaneously the coefficients on all lags of each variable in each equation, for a total of 49 tests per estimated VAR. ${ }^{7}$ Critical values were as tabulated by Andrews (1993). All tests used a heteroscedasticity-robust variancecovariance matrix. We found considerable evidence of instability in the earlier part of the sample; our number of rejections of parameter stability became less than the number expected under the null of no break only when the start date was 1975:1 or later. Since this date in any case marked the beginning of the current policy regime, we began all our VAR analyses with that date. We were not able to reject the null of

(1995) use an error-correction specification, but it does not appear to have important effects on their results.

${ }^{7}$ Testing all lags of each variable in each equation seemed a reasonable compromise between testing each coefficient separately--which would not have been informative about the stability of the qualitative dynamic properties of: the system--and testing all coefficients in the system, which would have lacked power. We also performed tests of stability equation-by-equation, with similar results to those reported in the text. 
stability of the reduced-form parameters for the sample period beginning in 1975:1 and ending in 1990:6.

Bernanke and Mihov (1995) focused on the case without discount rate shocks (Lombard rate shocks, in our context), which is both the simpler and the more comparable with the prior literature on VAR-based monetary indicators. As a preliminary exercise, we estimated the analogous case for Germany, which of course restricted us to consideration of the call rate and nonborrowed reserves as potential policy indicators. We used a six-variable VAR (omitting the Lombard rate), and we set to zero the Lombard rate innovation and the associated parameters $\gamma^{d}, \gamma^{b}, \gamma^{n}$, and $\phi^{s}$. To see if changes in the instruments available to the Bundesbank had had any effect, we estimated the model for the first ten years and last ten years of the sample, as well as for the whole fifteen-year sample (re-estimating the VAR each time). The last ten years of the sample (1980:7-1990:6) correspond roughly to the period following the introduction of repos; the first ten-year period (1975:1-1985:1) ends at the date that the Lombard rate became a penalty rate, exceeding the call rate for the first time.

The results are shown in Table 1 . They are reasonable and fairly comparable to the U.S. results of Bernanke and Mihov (1995). The slope of the reserves demand function, $\alpha$, is generally found to be small and insignificantly different from zero, although larger in the nonborrowed reserves model, as in the U.S. (Strongin, 1995, argues on institutional grounds that the assumption $\alpha=0$ is valid for the U.S.) The slope of the borrowings function, $\beta$, is of the right sign, precisely estimated, and fairly stable across subsamples. The more interesting findings are the tests of the overidentifying restrictions: First, the nonborrowed reserves model is rejected in the full sample and the first subsample (it does somewhat better in the latter subsample, being rejected at the 
108 level but not at the 58 level). Second, the call rate model is not rejected in the full sample. (P-values are obtained for Hansen's J test.) These two results are consistent with the usual characterization of Bundesbank operating procedures as focusing on interest-rate stabilization in the short run. Third, the call rate model does much better in the subsample beginning in 1980 ( $p=0.947$ ) than it does in the subsample ending in 1985 ( $p=0.093)$. This is at least a bit of evidence in favor of our hypothesis that the Bundesbank was less able to target open-market interest rates prior to the advent of repos and increased use of open-market operations.

We turn now to the results from the full model, including the Lombard rate and the associated equation, eq. (2.10). The estimates, to be found in Table 2, are based on the full seven-variable VAR, described above. Since we did not reject stability of the reduced-form VAR parameters, we use residuals from the VAR estimated for the entire 1975:1-1990:6 sample to obtain estimated structural parameters for the various subsamples. We did however find evidence of a break in the variance-covariance matrix of VAR residuals in 1981:6; hence we break several subsamples at that point (which also corresponds roughly to the introduction of repos), as well as 1985:1 (when the Lombard rate began to exceed the call rate). The set of parameters for which estimates are reported differs across models in Table 3, because the alternative models impose different restrictions.

We skip discussion of the parameter estimates and go directly to the p-values for the overidentifying restrictions, which form our basis for choosing among models. Again the nonborrowed reserves model is strongly rejected for the sample as a whole and for the earlier subsamples; however, it cannot be rejected for the subsample beginning in 1981 and does particularly well for the post-1985 period. 
Comparing the call rate and Lombard rate models, we find that neither is rejected in either the whole sample or in any subsample. To some extent this is a disappointing finding, since we are therefore not able to discriminate sharply between these two candidate indicators of German monetary policy. ${ }^{\circ}$ However, comparison of p-values does yield some interesting points. In particular, note that the call rate model achieves a much higher p-value $(0.881)$ in the period following the introduction of repos than in the earlier period (0.116), consistent with arguments made above. Similarly, the Lombard rate model is far from being rejected in the pre-1985 period, before the Lombard rate became a penalty rate $(p=0.925)$; after 1985 , this model does relatively less well $(p=0.423)$. A somewhat anomalous result is that the Lombard rate nevertheless achieves a better p-value than the call rate in the last, short sample period, 1985-1990. Judging by the estimate of $\phi^{d}$ from the Lombard rate model, which is only 0.114 and not statistically different from zero, and by the earlier finding that the nonborrowed reserves model does well in the post-1985 period, there appears to be evidence of reduced smoothing of market interest rates during the pre-unification period.

overall, although the data do not speak very strongly, the results suggest a slight preference of the Lombard rate over the call rate as an indicator of Bundesbank policy for the pre-1990 period. The Lombard rate has a (marginally) higher p-value for the whole sample, and for three of the four subsamples considered. From an a priori perspective, the weakest case for the Lombard rate should be in the 1985-1990 period,

${ }^{8}$ In early estimations using the entire sample we were able to strongly reject the call rate in favor of the Lombard rate, a finding that motivated us to pursue this line further. It appears now that this rejection was due somehow to the instability of the first-stage VAR in the early 1970s. However, this result may still be taken as a cautionary note to those considering the call rate as an indicator for the period prior to 1975 . 
when this rate became a penalty rate. Yet as Table 2 shows, the Lombard rate is not close to being rejected as an indicator for this subperiod, and its movements after 1985 were very close to those of the call rate. For these reasons, we use the Lombard rate as the main policy indicator in the exercises of section 3. However, we also check the robustness of our results to the use of the call rate and a combination of the Lombard rate and the call rate.

Figure 2 shows the dynamic responses of industrial production and the CPI to innovations in the call rate and the Lombard rate, the two non-rejected indicators. These impulse responses are calculated from four-variable VARs including the same set of non-policy variables as above plus the relevant indicator. The main point of interest is that, unlike the call rate, the response of the price level to Lombard rate innovations does not exhibit the "price puzzle". The statistical uncertainty about this result is large, but we nevertheless find it encouraging for the use of the Lombard rate as a policy indicator.

\section{The Bundesbank: closet inflation targeter?}

We are prepared now to try to answer the question posed by the introduction, of whether the Bundesbank is better characterized as an inflation targeter or as a money targeter. We first briefly discuss some historical evidence, then turn to our statistical test.

Although the Bundesbank has publicly emphasized the importance of money targets in its policy-making since 1975, it has been often noted that these money targets are tied to projections of inflation and potential output growth through the quantity equation relationship (von Hagen, 1995; Bernanke and Mishkin, 1992; von Hagen and Neumann, 1993). Our attempt to reconstruct that calculation from Bundesbank reports is shown in Table 3. The column labelled "money growth target" shows the 
official ex ante targets (for growth of central bank money prior to 1988, M3 growth thereafter), as set in December prior to the year to which the target applies. As in von Hagen (1995), what we have labelled the "inflation target" is the announced rate of "unavoidable inflation" for 1975-1985; after 1985, the inflation target is always set to $2.0 \%$, which the Bundesbank has deemed to be the rate consistent with "price stability". Also given are the Bundesbank's estimates of growth of "production potential" and their stated adjustment for velocity. By the Bundesbank's procedure the money growth target should be the sum of the inflation target and forecasted potential output growth, less the velocity adjustment. This is usually the case (or nearly so) in Table 3, although note that after 1978 money growth targets are generally set as a range rather than as a point. ${ }^{9}$

The impression one receives from the table is that, for the most part, the Bundesbank has made its money growth targets subservient to its inflation targets. Note that the inflation targets decline steadily (except in the oil-shock year, 1980), and are considerably less volatile than the money growth targets; and that, as mentioned, money growth targets are usually specified as ranges, while inflation targets are points (except in 1981). Also, on one occasion (1987) the Bundesbank changed its targeted money aggregate, an event that occurred when abovetarget money growth coincided with below-target inflation.

The Bundesbank has subjugated its money growth objective to its inflation objective in another sense, in its willingness to deviate from money growth targets to offset unexpected inflation. This point--which has been emphasized by von Hagen (1995)--is also illustrated in Table 3 , by the columns which show targets, outcomes, and deviations from targets

\footnotetext{
9 Part of the discrepancy between the actual money growth targets and the targets implied by the quantity-theory calculation arises because inflation rates are expressed as annual averages while money growth rates (after 1978) are measured fourth quarter to fourth quarter.
} 
(or from the middle of target ranges) for both money growth and

inflation. At least through unification in 1990, the record indicates a clear negative relationship between deviations of money growth from target and deviations of inflation from target, suggesting a willingness of the Bundesbank to "lean against the (inflationary) wind". (The regression coefficient of the money growth deviation on the inflation deviation for 1975-1990 is -0.872 , with a t-statistic of 4.0.) Indeed, the Bundesbank achieves its target range for money in only a minority of cases. However, after 1990 there has been at least a temporary change in behavior, with inflation and money growth tending to deviate in the same instead of opposite directions.

Despite these indications that the Bundesbank is "really" an inflation targeter, such a conclusion would not fit entirely with the Bundesbank's own claims. For example, a recent official publication (Deutsche Bundesbank, 1995) includes the following commentary:

"More recently, the central banks of some countries (e.g. Canada, New Zealand, the United Kingdom, Finland) have abandoned the practice of setting an intermediate target and switched to targeting the final goal direct. However, the transition to such a one-tier strategy of inflation targeting was not effected because such strategies are inherently superior--say, in terms of theoretical approach. It was effected not by choice but rather of necessity, since (particularly in the wake of radical change in the financial markets) the traditional monetary relationships had become unstable, and there was no longer a predictable correlation between the intermediate target variable and prices. The one-tier strategy would thus appear to be a "second-best" solution if a suitable intermediate target is no longer available...The disadvantages of such a multi-indicator approach lie in a very high degree of complexity, the associated lack of transparency for the general public and the risk of a certain disorientation of monetary policy decisions. For these reasons an intermediate target strategy is preferable to targeting the final goal direct as long as monetary policy has at its disposable an intermediate target variable which basically meets the above-mentioned requirements..." (pp. 67-8)

We take the above statement as asserting the view that targeting money growth can be superior to targeting the forecast of inflation-notwithstanding Svensson's (1996) argument to the contrary--because 
money targeting is easier to explain to the public and perhaps because it limits the scope for poor policy decisions ("disorientation"). If this statement accurately reflects German policymakers' views, then clearly they must sometimes allow policy to respond to deviations of money growth from the projected path, even if inflation is on target.

In the remainder of this section we attempt to evaluate statistically whether the Bundesbank should be thought of as an inflation targeter or not. We do this by asking the question: Given forecasted inflation, do changes in forecasted money growth affect Bundesbank policy? And if so--to take the question one step further--is it because money growth is correlated with other goal variables of the Bundesbank, or because the Bundesbank considers it intrinsically desirable to hit its money target?

Although our test is an intuitive one, it may be useful to motivate it by a simple example. Consider an economy that lasts three periods, $t=0,1,2$. In period 0 , the $\log$ price level $p_{0}$, the log money supply $m_{0}$, and the central bank's policy instrument le.g., the overnight interest rate) $i_{0}$ are given and known. In periods 1 and 2 , prices and money evolve according to

(3.1) $p_{t}=m_{t}+\varepsilon_{p t}$

$$
\text { (3.2) } m_{t}=-b i_{t-1}+\varepsilon_{m s}
$$

Equation (3.1) says that prices depend on the money supply and other stochastic factors, such as velocity shocks. According to (3.2), the money stock in turn is affected by stochastic factors and (with a oneperiod lag) by the policy instrument. We assume for simplicity that the error terms affecting prices and money are random walks (it can be shown that our results hold for more general stochastic processes): 


$$
\begin{aligned}
& \varepsilon_{p t}=\varepsilon_{p, r-1}+\eta_{p t} \\
& \varepsilon_{m t}=\varepsilon_{m, t-1}+\eta_{m t}
\end{aligned}
$$

where the $\eta^{\prime}$ 's are i.i.d., mean-zero random variables.

Assume that in period 0 the central bank sets growth targets, for $t=0$ to $t=2$, for prices and money. From (3.1), we know that $E_{0}\left(p_{2}-p_{0}\right)=E_{0}\left(m_{2}-m_{0}\right)$, so consistency requires the targeted growth rates of prices and money to be the same; without significant loss of generality, set both of these targets to zero. Interim values of prices and money are realized in $t=1$; since $i_{0}$ is given, these interim values depend only on the realizations of $\eta_{p l}$ and $\eta_{m l}$. The question we want to ask is, how will the central bank adjust its policy instrument in the interim period, $i_{1}$, in response to its new information?

The answer depends, of course, on the central bank's objectives. Assume that, as of $t=1$, the central bank's loss function is

$$
E_{1}\left[\frac{1}{2}\left(p_{2}-p_{0}\right)^{2}+\frac{a}{2}\left(m_{2}-m_{0}\right)^{2}\right]+\frac{d}{2}\left(i_{1}-i_{0}\right)^{2}
$$

where $E_{1}[$.$] signifies the expectation conditional on information$ available in $t=1$, and $a$ and $d$ are non-negative parameters. Equation (3.4) says that the central bank's loss depends on the expected squared deviations of inflation and money growth from their targets, with $a$ the relative weight put on the money growth target per se; a "pure" inflation targeter sets $a=0$, i.e., it cares about money growth only insofar as it affects inflation. The last term in (3.4) captures an interest-rate-smoothing motive, for which there is considerable evidence, both formal and informal.

Minimizing the loss function (3.4) yields the optimal value of the policy instrument in period $1, i_{1}^{*}$ : 
(3.5) $\quad i_{1}^{*}=\frac{b\left(\varepsilon_{m l}+\varepsilon_{p 1}-p_{0}\right)+a b\left(\varepsilon_{m l}-m_{0}\right)+d i_{0}}{b^{2}(1+a)+d}$

The innovation in $i_{1}^{*}$, relative to its expectation as of period 0 , is

(3.6) $\quad i_{1}^{*}-E_{0} i_{1}^{*}=\frac{b\left[\left(\eta_{m 1}+\eta_{p 1}\right)+a \eta_{m 1}\right]}{b^{2}(1+a)+d}$

The innovation in the policy instrument can be related to the innovations in the forecasts of inflation and money growth. Using the facts that the revision in the inflation forecast, $E_{1} p_{2}-E_{0} p_{2}$, equals $-b\left(i_{1}^{*}-E_{0} i_{1}^{*}\right)+\eta_{m 1}+\eta_{p 1} ;$ and, similarly, that the revision in the money growth forecast, $E_{1} m_{2}-E_{0} m_{2}$, equals $-b\left(i_{1}^{*}-E_{0} i_{1}^{*}\right)+\eta_{m 1}$, some algebra reveals that (3.7) $\quad i_{1}^{*}-E_{0} i_{1}^{*}=\frac{b}{d}\left[\left(E_{1} p_{2}-E_{0} p_{2}\right)+a\left(E_{1} m_{2}-E_{0} m_{2}\right)\right]$

That is, the innovation in the policy instrument responds to interim innovations in the forecasts of inflation and money growth, with a relative weight that depends on the importance of money deviations in the central bank's loss function. In particular, if the central bank is a "pure" inflation targeter, and it therefore puts no weight on deviations of money from target except insofar as money affects inflation $(a=0)$, then changes in the instrument will be related only to changes in forecasted inflation and not, given forecasted inflation, to changes in forecasted money growth. In contrast, if money growth enters the objective function independently, then the policy instrument will respond to changes in forecasted money growth even if forecasted inflation is held constant. More generally, if additional factors besides inflation and money growth are of concern to the central bank, changes in the forecasts of these variables will have marginal 
predictive power for the policy instrument, given forecasts of inflation and money.

These insights provide the basis for our test of the inflationtargeting propensities of the Bundesbank. ${ }^{10}$ We began by constructing monthly time series of twelve-month-ahead forecasts for inflation, money growth, and other variables to be specified in a moment. In-sample forecasts were constructed from a six-variable VAR including the three non-policy variables, the Lombard rate, money, and the exchange rate. ${ }^{11}$ The in-sample, twelve-month-ahead forecasts of inflation obtained by this method fit closely with the series of Bundesbank inflation targets as shown in Table 3.

Our main tests of the determinants of German monetary policy are given in Table 4. The basic result is illustrated by the first column of numbers corresponding to Equation 1, under the heading "Lombard rate" (ignore the other columns for now). These results are drawn from a twelve-lag VAR including three variables: the forecast for inflation over the next twelve months, at each date; the forecast for money growth (CBM before 1988, M3 afterwards), at each date; and the Lombard rate. The question we ask is: Given twelve lags of the inflation forecast and

10 In his comment on this paper at the conference, Larry Christiano pointed out another implication of this framework: namely, that deviations of inflation from target should be unforecastable. Equivalently, the best statistical forecast of inflation should always equal the official target. These implications are rejected by the data at most horizons, but (like the analogous "random-walk" tests of the permanent-income hypothesis) these rejections do not shed much light on the quantitative significance of the deviation from inflation targeting. For this reason we prefer the test described in the text.

"We compared in-sample forecasts of inflation and other variables based (1) on an autoregression; (2) on the "base" VAR, including the three non-policy variables and the Lombard rate; and (3) on the base VAR augmented by various combinations of the log of the money stock (CBM spliced to $M 3$ in 1988) and the log of the DM/dollar exchange rate, twelve monthly lags being used in all cases. Statistical tests (including Granger-causality and block-exogeneity tests) favored the inclusion of both the money stock and the exchange rate in the forecasting equations. In particular, the fact that money contains significant marginal information about future inflation is interesting, given the claim that money is targeted for that very reason. 
twelve lags of the Lombard rate itself, do lags of the money growth forecast have additional predictive power for the Lombard rate? ${ }^{12}$ In a Granger sense, Table 4 shows that the answer is yes: Both inflation forecasts and money forecasts Granger-cause the Lombard rate at better than a 58 level. Thus there is some evidence that the money forecast affects Bundesbank policy decisions, even given the inflation forecast. But how big is this effect? The second part of Table 4 shows the percentage of the forecast variance for the Lombard rate explained at different horizons by innovations to each of the three variables in the VAR. We find that at short horizons the forecast error for the Lombard rate is dominated by its own shocks, and at longer horizons it is dominated by shocks to the inflation forecast. Shocks to the money growth forecast do not play an important role quantitatively in determining the Lombard rate at any horizon. This is the basis for our conclusion that the Bundesbank is better characterized as an inflation targeter than as a money targeter.

It would be interesting to know whether the Granger-causal relationship between money growth forecasts and the Lombard rate arises because the Bundesbank is interested in money growth per se, or because money growth forecasts goal variables other than inflation. Equations 2 and 3 in Table 4 add sequentially the one-year forecasts of industrial production growth and nominal exchange-rate (DM/\$) depreciation. (Exchange-rate depreciation is ordered after, rather than before the Lombard rate on the grounds that exchange rates are not a "slow-moving" variable, like inflation or output; this ordering modestly reduces the share of forecast variance attributed to the exchange rate, but of

\footnotetext{
12 The example presented above suggests that we should relate innovations in the Lombard rate only to innovations in contemporaneous forecasts. We include lagged forecasts in our test to allow for outside (information-gathering) and inside (decision-making) lags in the policy process.
} 
course does not affect the Granger-causality statistics.) We find that the money growth forecast continues to Granger-cause the Lombard rate at the 58 level in both cases, suggesting that the Bundesbank pays attention to money growth for some reason (establishment of credibility, perhaps) not directly related to its predictive power for ultimate goal variables. There is also some evidence, consistent with what others have found, that the Bundesbank pays attention to ultimate objectives other than inflation: Forecasted output Granger-causes the Lombard rate in the presence of the other variables, and makes some contribution to the forecast variance decomposition as well. The expected rate of exchange rate depreciation does not Granger-cause the Lombard rate, but it has some effect on the Lombard rate's forecast error at longer horizons. (This latter result is difficult to interpret; it may arise from the collinearity of expected exchange rate depreciation and expected inflation.) Our main result survives, however, in that innovations to inflation forecasts continue to play a large role, and innovations to money growth forecasts a small role, in the determination of Lombard rate forecast errors.

To check that these results do not depend on the use of the Lombard rate as the policy indicator, we repeated all of these tests using as the indicator a) the call rate, and b) a "spliced" series based on the Lombard rate prior to 1985 and the call rate afterwards. ${ }^{13}$ The Granger-causality results using the alternative indicators are shown in the second and third columns of numbers in the top half of Table 4. The results for the call rate seem even stronger than for the Lombard rate: The inflation forecast always Granger-causes the call rate at the 58 level, while the money growth forecast never does. For the spliced

${ }^{13}$ We also considered using the repo rate. However, this rate is available for a shorter period and is very close to the call rate over the period for which it is available. 
series, inflation forecasts Granger-cause the policy indicator at the 58 level in the presence of money and output forecasts, but only at the 10 z level when an exchange rate forecast is added. Variance decomposition exercises for the alternative indicators (not shown to conserve space) looked quite similar to those for the Lombard rate, confirming the dominance of inflation forecasts as a determinant of German monetary policy actions, particularly at longer horizons. ${ }^{14}$

As a final exercise, we use the largest VAR from Table 4 (with the Lombard rate as the policy indicator) to study the response of the system to an innovation in the inflation forecast. The impulse responses, shown in Figure 3, convey a plausible story: A positive innovation to the inflation forecast leads to a policy tightening, as captured by a rise in the Lombard rate. Forecasted output growth declines, as would be expected, and the rate of expected depreciation of the exchange rate rises. ${ }^{15}$ Most interesting, though, is that the forecasted rate of money growth falls in an almost mirror image of the increase in forecasted inflation. This pattern seems to confirm the "leaning against the wind" story told by von Hagen (1995) and others.

\section{Conclusion}

Our main conclusion has been amply foreshadowed. In brief, although the Bundesbank uses money growth as an important informational variable and operating guide, and despite its protestations to the

\footnotetext{
14 We also ran our tests using the forecasted deviations of inflation and money growth from the official targets (and of output and exchange rates from their Hodrick-Prescott trends) in place of the simple forecasts. In doing so, we experimented with different assumptions about the willingness of the Bundesbank to try to offset previous overshooting or undershooting of targets. The results were not much different from those reported in Table 4 .

${ }^{15}$ It is probably dangerous to overinterpret the latter finding, given the asset-price nature of exchange rates. Possible explanations for an increased rate of expected depreciation include an overshooting effect from money tightening, and the information effect of the increased rate of anticipated inflation.
} 
contrary, it seems to be better characterized as an inflation targeter than as a money targeter. Following the example set by German monetary policy should not be construed as rigid adherence to money growth targets, a practice which the Bundesbank itself has not followed. 


\section{Appendix. What is a monetary policy shock?}

VAR-based analyses of monetary policy have proliferated in recent years, both in academic research and in policy-making. This widespread use reflects the method's strengths, notably its simplicity and its tendency to deliver "reasonable" results. As should be expected for any novel methodology, the VAR-based approach has also drawn its share of criticism--some justified, of course, but some less so. In this appendix we use simple examples to address two questions that have been raised about the central concept of "shocks" to monetary policy, as follows :

(1) What is the source of monetary policy shocks?

(2) Why draw a distinction between innovations to the money supply and innovations to monetary policy?

(1) Some critics have questioned the concept of "shocks" to monetary policy. They point out that the Fed and the Bundesbank certainly do not randomize their policy actions explicitly, and that any errors made in the implementation of policies are likely to be quickly reversed. How then could shocks to policy be large enough to matter? In general, all that is necessary for what we call a policy shock to occur is that the policy decision be influenced by some factor (personalities, beliefs, political considerations, problems of measurement or interpretation) that is imperfectly correlated with the current state of the economy. In the following example we illustrate that valid (in the sense required by our paper) policy shocks can be generated from two realistic sources: (a) imperfect information on the part of the central bank about the current economy, and (b) changes in the relative weights put by the central bank on moderating fluctuations in output and inflation. In particular, neither explicit randomization 
nor persistent implementation errors are needed to generate meaningful policy shocks.

Consider the following simple economy:

(A.1) $\quad y_{t}=m_{t}-p_{t}+x_{t}$

(A.2) $m_{t}=m_{t-1}-\beta \hat{x}_{t}$

(A. 3) $\hat{x}_{1}=x_{t}+\eta_{t}$

(A. 4) $\quad p_{t}=E_{t-1} m_{t}=m_{t-1}$

Equation (A.1) says that output $y$ is determined by real money balances $m-p$ and a supply shock $x$ that we take to be i.i.d. with mean zero. The central bank's policy reaction function is described by (A.2): The change in the money supply between periods $t-1$ and $t$ is inversely related to the supply shock observed by the central bank at $t$. (We give further justification of this assumption below; later we also relax the assumption that the money supply is the operating instrument). However, the central bank does not observe the contemporaneous supply shock; instead it obsersves (and bases its policy on) a noisy measure of the supply shock $\hat{\boldsymbol{x}}$, which is equal to the actual shock plus uncorrelated measurement error (eq. (A.3)). We assume the error in observation reflects lags in data collection, revisions, etc., which obscure the true state of the economy for one period only; hence both the Fed and the econometrician can observe past values of the supply shock without error. Finally, we assume that prices prevailing in period $t$ are set at the end of $t-1$, using only information available in $t-1$. If we assume that prices are set so that the expected value of output equals its full-employment level (which we normalize to zero), than it is straightforward to deduce that prices will equal the expected money stock, which in turn equals the lagged money stock (eq. (A.4)). 
The solution for output, expected inflation, and the money supply in period $t$ is

(A. 5) $\quad y_{t}=x_{t}-\beta\left(x_{t}+\eta_{t}\right)$

(A. 6) $\quad p_{t+1}-p_{t}=-\beta\left(x_{t}+\eta_{t}\right)$

(A. 7) $m_{t}=m_{t-1}-\beta\left(x_{t}+\eta_{t}\right)$

Note that the solution involves simultaneous determination of the macro variables and the money supply. Thus this example does not literally conform to the framework used in this paper, which bases identification on the assumption that policy shocks affect macro variables only with a one-period delay. However, the assumption of simultaneity is for simplicity only and could be eliminated by a more complicated specification; it does not affect the focus of this example, which is the interpretation of policy shocks.

Now we suppose that the econometrician estimates the central bank's reaction function (A.7), using her ex post knowledge of the supply shock in period t. (Note that this provides a rationalization for using revised data, that was not known contemporaneously to the Fed, when estimating the reaction function.) In this case the policy shock $v^{s}$ would be consistently estimated by a least-squares regression of money on the supply shock to be:

$$
\text { (A. 8) } \quad v_{1}^{s}=-\beta \eta_{1}
$$

Given this policy shock, the econometrician can correctly estimate the effects of monetary policy shocks on the economy, i.e., from (A.5) and (A. 6) : 
(A. 8) $\frac{\partial y_{t}}{\partial v_{t}^{s}}=1, \quad \frac{\partial\left(p_{t+1}-p_{l}\right)}{\partial v_{t}^{s}}=1$

This first example shows that data errors and revisions provide a possible source of policy shocks. An alternative rationalization is random preferences on the part of the central bank: To illustrate this possibility, suppose now that the central bank observes the supply shock perfectly within the period (so that $\eta=0$ ) but chooses its reaction coefficient $\beta$ in each period to minimize the value of the following period-by-period loss function in the variances of inflation and output:
(A. 9)

$$
L=\left(p_{t+1}-p_{t}\right)^{2}+\theta y_{t}^{2}
$$

where $\theta$ is the weight on output deviations from full employment. Using the model (A.1)-(A.4) above but with the measurement error set to zero, we find that the value of $\beta$ that minimizes (A.9) is given by

$$
\text { (A. 10) } \beta=\frac{\theta}{1+\theta}
$$

Now suppose that the central bank's aversion to output fluctuations $\theta$ is a stationary random variable, so that $\beta$ is as well. Let the mean of $\beta$ be $\bar{\beta}$. The reaction function (A.2) can now be written
(A. 11) $m_{t}=m_{t-1}-\bar{\beta} x_{t}-(\beta,-\bar{\beta}) x_{t}$. 
If we make the assumption of statistical independence between the shock to central bank preferences and the supply shock (implying that $E_{t-1}\left[\left(\beta_{t}-\bar{\beta}\right) x_{t}\right]=0$ ), then the solution for output and inflation is

(A.12) $y_{t}=(1-\bar{\beta}) x_{t}-\left(\beta_{t}-\bar{\beta}\right) x_{t}$

(A. 13) $\quad p_{t+1}-p_{t}=-\bar{\beta} x_{t}-\left(\beta_{t}-\bar{\beta}\right) x_{t}$

Here we can identify the monetary policy shock with the random part of the reaction function, eq. (A.11):

(A.14) $v_{1}^{s}=-(\beta,-\bar{\beta}) x_{1}$

Despite the presence of the supply shock term in (A.14), which would induce a form of heteroscedasticity, the assumption that random fluctuations in central bank preferences are independent of the supply shock is sufficient to permit the monetary policy shock term to be extracted from (A.11) by least-squares regression. Again, as (A.12) and (A.13) show, if supply shocks are controlled for, the estimated policy innovations could be used to correctly identify the effects of monetary

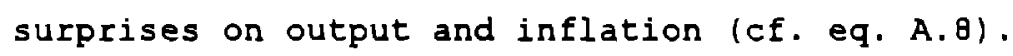

(2) In the example above the policy shock was identified with the innovation to the money supply. To show that this is not always correct, and to reinforce the point that it is important to base the identification of policy shocks on knowledge of the central bank's operating procedure, consider the following simple model of the type explored by Sargent and Wallace (1975): 
(A. 15) $y_{t}=-b\left[R_{t}-\left(E_{t} p_{t+1}-p_{t}\right)\right]+e_{t}^{1}$

(A. 16) $m_{1}-p_{t}=c y_{1}-d R_{1}+e_{1}^{2}$

(A.17) $y_{t}=g\left(p_{t}-E_{t-1} p_{t}\right)+e_{t}^{3}$

Equations (A.15)-(A.17) are an IS relationship, a money demand equation, and a Lucas-type aggregate supply curve respectively. $R$ is the oneperiod nominal interest rate, and the $e^{i}$ are mean-zero, i.i.d., mutually uncorrelated shocks. Note that in this example prices are not predetermined, but aggregate supply depends on the deviation of actual from anticipated prices.

Consider two cases. In the first case, called money targeting, the central bank sets the money supply equal to its lagged value plus an unpredictable disturbance, $\eta^{M}$ :

(A. 18) $\quad m_{t}=m_{t-1}+\eta_{t}^{M}$

Note that, under money targeting, the money supply does not respond to the contemporaneous non-policy shocks $e_{i}^{i}$. In the second case, called interest-rate targeting, monetary policy is used to set the nominal interest rate equal to its equilibrium value (which is zero, if we maintain the martingale assumption for the money stock) plus an unpredictable disturbance, $\eta^{R}$ :
(A. 19) $R_{t}=\eta_{t}^{R}$ 
Rational-expectations solutions of the model conditional on the lagged money stock can be obtained by the method of undetermined coefficients. For the case of money targeting, the solution is

$$
\left|\begin{array}{c}
y_{t} \\
p_{t}-m_{t-1} \\
R_{t} \\
m_{t}-m_{t-1}
\end{array}\right|=\Delta_{M}^{-1}\left|\begin{array}{cccc}
d g & -b g & b(1+d) & b g(1+d) \\
d & -b & -(b c+d) & b(1+d) \\
1+c g & b+g & b c-1 & g(b c-1) \\
0 & 0 & 0 & 1
\end{array}\right|\left|\begin{array}{c}
e_{t}^{1} \\
e_{t}^{2} \\
e_{t}^{3} \\
\eta_{t}^{M}
\end{array}\right|
$$

where $\Delta_{M}=d(b+g)+b(1+c g)$.

For interest-rate targeting, the solution is

$$
\left|\begin{array}{c}
y_{t} \\
p_{t}-m_{t-1} \\
R_{t} \\
m_{t}-m_{t-1}
\end{array}\right|=\Delta_{R}^{-1}\left|\begin{array}{cccc}
g & b g & 0 & -b g(1+d) \\
1 & b & b c-1 & -b(1+d) \\
0 & 0 & 0 & 1 \\
1+c g & b+g & b c-1 & -b(1+c g)-d(b+g)
\end{array}\right|\left|\begin{array}{c}
e_{t}^{1} \\
e_{t}^{2} \\
e_{t}^{3} \\
\eta_{t}^{R}
\end{array}\right|
$$

where $\Delta_{R}=g(1-b c)$.

Now suppose that we want to recover the effect of a one-unit, autonomous innovation in the money stock on an endogenous variable, say output. If the central bank is targeting money, so that innovations to the money supply are exogenous by assumption, then the desired magnitude can be read off directly from the the last column of the $4 \times 4$ matrix in (A.20); its value is $\frac{b g(1+d)}{b(1+c g)+d(b+g)}$. Under money targeting, this magnitude could be calculated as the regression coefficient of output residuals on money residuals. What if, instead, the central bank is targeting interest rates? Then, as the reader can verify from (A.21), the identical measure of the effect of a unit money shock can be 


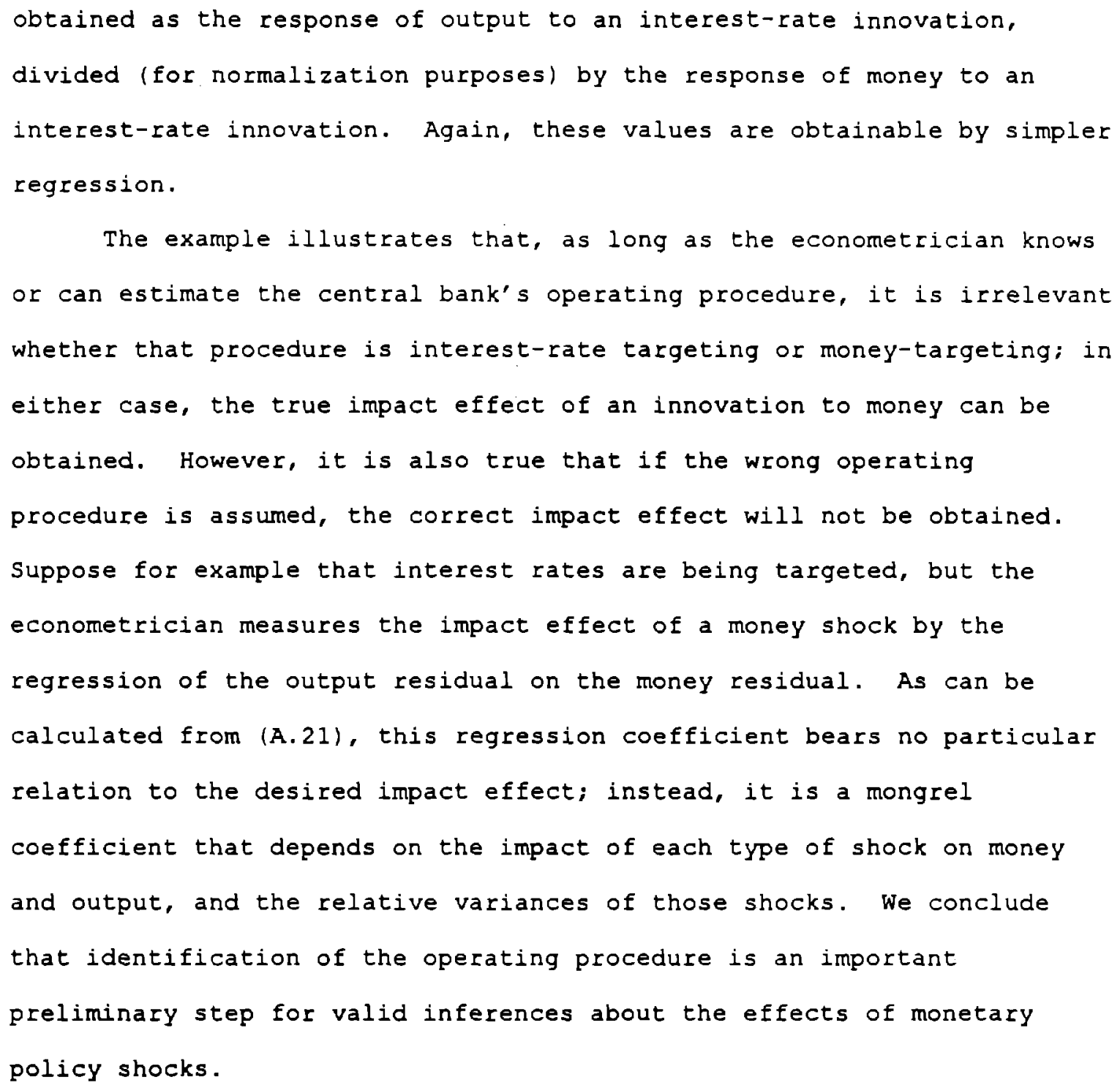




\section{Reference:}

Andrews, Donald W.K., "Tests for Parameter Instability and structural Change with Unknown Change Point", Econometrica 61, 1993, 821-56.

Barran, Fernando, Virginie Coudert, and Benoit Mojon, "The Transmission of Monetary Policy in the European Countries", Centre d'Etudes Prospectives et D'Informations Internationales, working paper no. 96-03, Eebruary 1996.

Batten, Dallas S., Michael P. Blackwell, In-Su Kim, Simon E. Nocera, and Yuzuru Ozeki, "The Conduct of Monetary Policy in the Major Industrial Countries: Instruments and Operating Procedures", International Monetary Fund, Occasional Paper no. 70, July 1990.

Bernanke, Ben, "Alternative Explanations of the Money-Income Correlation", in K. Brunner and A. Meltzer, eds., Real Business Cycles, Exchange Rates and Actual Policies, Carnegie-Rochester Conference Series on Public Policy no. 25, Amsterdam: North-Holland, 1986.

Bernanke, Ben and Alan Blinder, "The Federal Funds Rate and the Channels of Monetary Transmission", American Economic Review 82, September 1992, 901-21.

Bernanke, Ben and Ilian Mihov, "Measuring Monetary Policy", National Bureau of Economic Research working paper no. 5145, June 1995.

Bernanke, Ben and Frederic Mishkin, "Central Bank Behavior and the Strategy of Monetary Policy: Observations from Six Industrial Countries", in Olivier Blanchard and Stanley Fischer, eds., NBER Macroeconomics Annual, 1992.

Christiano, Lawrence and Martin Eichenbaum, "Identification and the Liquidity Effect of a Monetary Policy Shock", in A. Cukierman, $z$. Hercowitz, and L. Leiderman, eds., Political Economy, Growth, and Business Cycles, Cambridge MA: MIT Press, 1992.

Christiano, Lawrence, Martin Eichenbaum, and Charles Evans, "Identification and the Effects of Monetary Policy Shocks", Federal Reserve Bank of Chicago, working paper WP-94-7, May 1994.

Clarida, Richard, and Mark Gertler, "How the Bundesbank Conducts Monetary Policy", unpublished, Columbia University and NYU, December 1995.

Deutsche Bundesbank, The Monetary Policy of the Bundesbank, October 1995.

Gerlach, Stefan and Frank Smets, "The Monetary Transmission Mechanism: Evidence from the G-7 Countries", in Financial Structure and the Monetary Policy Transmission Mechanism, Basle: Bank for International Settlements, 1995.

Goodhart, Charles A.E. and Jose' Vinals, "strategy and Tactics of Monetary Policy: Examples from Europe and the Antipodes", in Jeffrey C. Fuhrer, ed., Goals, Guidelines, and Constraints Facing Monetary Policymakers, Federal Reserve Bank of Boston, conf. series no. 38, 1994. 
Haldane, Andrew G., ed., Targeting Inflation, Bank of England, 1995.

Kahn, George and Kristina Jacobson, "Lessons from West German Monetary Policy", Eederal Reserve Bank of Kansas City, Economic Review, April $1989,18-35$.

Kasman, Bruce, "A Comparison of Monetary Policy Operating Procedures in Six Industrial Countries", Federal Reserve Bank of New York, Quarterly Review, Summer 1992, 5-24.

Kneeshaw, J.T. and P. Van den Bergh, "Changes in Central Bank Money Market Operating Procedures in the 1980s", Bank for International Settlements (Basle), BIS Economic Papers no. 23, January 1989.

Leiderman, Leonardo, and Lars E.O. Svensson, Inflation Targets, London: Centre for Economic Policy Research, 1995.

Sargent, Thomas J. and Neil Wallace, "'Rational' Expectations, the Optimal Monetary Instrument, and the Optimal Money Supply Rule", Journal of Political Economy 83, 1975, 214-54.

Sims, Christopher, "Macroeconomics and Reality", Econometrica 48, 1980, $1-48$.

, "Interpreting the Macroeconomic Time Series Facts: The Effects of Monetary Policy", European Economic Review 36, 1992, 9751011 .

Svensson, Lars, "Inflation Forecast Targeting: Implementing and Monitoring Inflation Targets", IIER, Stockholm University (this journall.

Trehan, Bharat, "The Practice of Monetary Targeting: A Case Study of the West German Experience", Federal Reserve Bank of San Francisco, Economic Review, Spring 1988, 30-34.

Tsatsaronis, Costas, "Is There a Credit Channel in the Transmission of Monetary Policy? Evidence from Four Countries", in Financial structure and the Monetary Policy Transmission Mechanism, Basle: Bank for International Settlements, 1995

von Hagen, Jurgen, "Monetary Targeting with Exchange Rate Constraints: The Bundesbank in the 1980s", Federal Reserve Bank of St. Louis, Review, vol. 71 no 5, September/October 1989, 53-69.

- "Inflation and Monetary Targeting in Germany", in Leonardo Leiderman and Lars E.O. Svensson, Inflation Targets, London: Centre for Economic Policy Research, 1995.

von Hagen, Jurgen and Manfred J.M. Neumann, "Germany", in M. Fratianni and D. Salvatore, eds., Handbook of Monetary Policy in Industrialized Countries, Westport CT: Greenwood, 1993. 
Table 1. Estimates of models of the operating procedure (6-variable VAR)

a. Call rate model

Restrictions: $1-\phi^{d}=0,1+\phi^{b}=0$

Sample

Parameter estimates

period

$\alpha$

$$
\beta \quad \sigma^{d}
$$

$$
\sigma^{b}
$$

Test of

$1975: 1-$

.00104

.0045

.0150

$(.0003)(.0010)(.0014)$

$1975: 1-$

$-.0004$

) $(.0041)$

$(.00117)(.0055)$

.0052

.0198

.0059

1985: 1

$-.00108 \quad .0188$

$(.0004)$

$1980: 7-$

$(.00142)(.0054)$

.0034

$(.0002)(.0009)(.0013)$

.0118

$(.0025)$

$1990: 6$

b. Nonborrowed reserves model

$$
\text { Restrictions: } \phi^{d}=0, \phi^{b}=0
$$

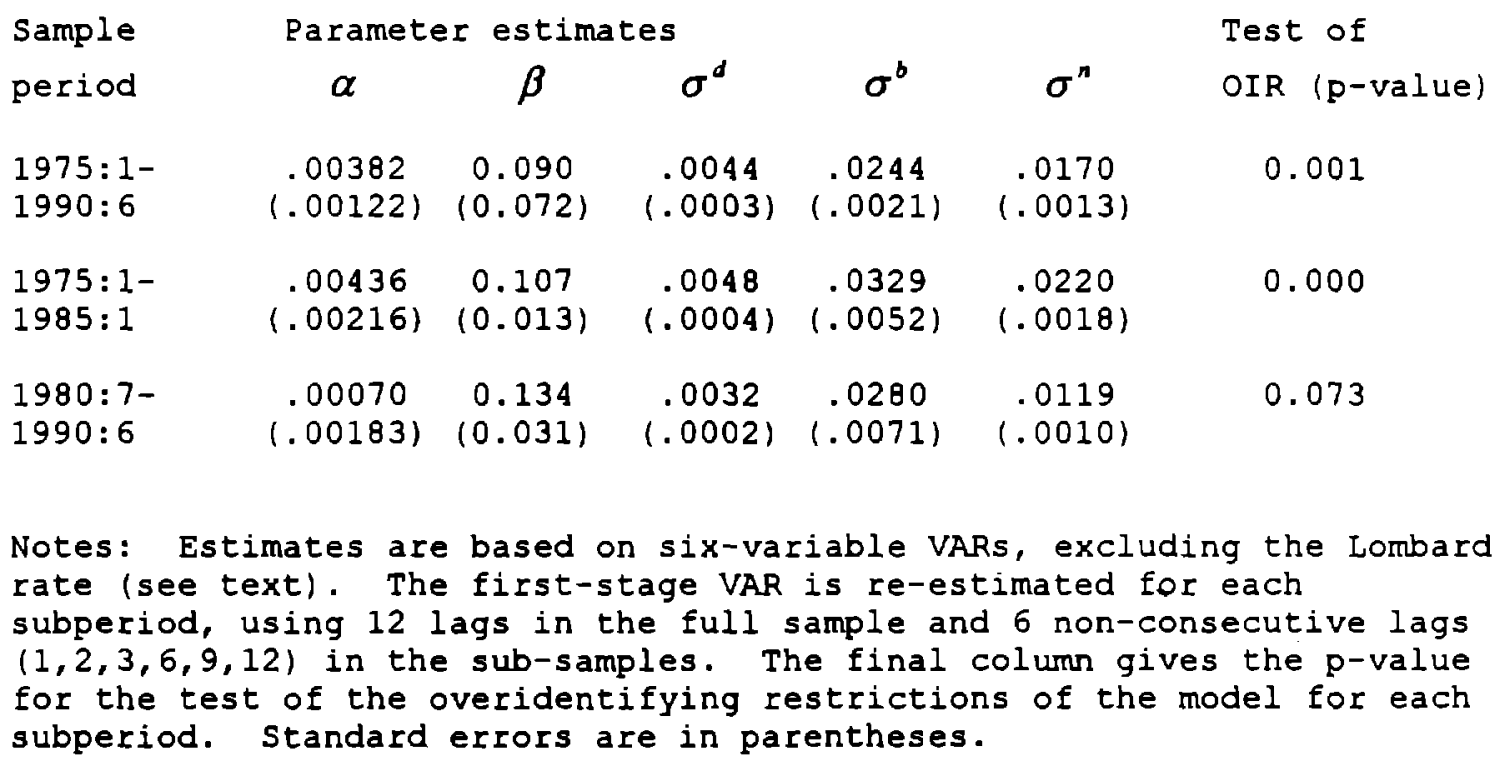


Table 2. Estimates of models of the operating procedure (7-variable VAR)

a. Call rate model

$$
\text { Restrictions: } 1-\phi^{d}+\beta \gamma^{d}=0,1+\phi^{b}-\beta \gamma^{b}=0, \phi^{s}=0
$$

\begin{tabular}{|c|c|c|c|c|c|c|}
\hline \multirow{2}{*}{$\begin{array}{l}\text { Sample } \\
\text { period }\end{array}$} & \multicolumn{5}{|c|}{ Parameter estimates } & Test of \\
\hline & $\alpha$ & $\beta$ & $\phi^{d}$ & $\phi^{b}$ & $\gamma^{n}$ & OIR (p-value) \\
\hline $\begin{array}{l}1975: 1- \\
1990: 6\end{array}$ & $\begin{array}{l}.00016 \\
(.00315)\end{array}$ & $\begin{array}{l}.0156 \\
(.0178)\end{array}$ & $\begin{array}{c}0.918 \\
(0.341)\end{array}$ & $\begin{array}{l}-0.986 \\
(0.159)\end{array}$ & $\begin{array}{l}-7.91 \\
(23.2)\end{array}$ & 0.427 \\
\hline $\begin{array}{l}1975: 1- \\
1981: 6\end{array}$ & $\begin{array}{l}-.00004 \\
(.01704)\end{array}$ & $\begin{array}{l}.0123 \\
(.0077)\end{array}$ & $\begin{array}{c}0.934 \\
(1.547)\end{array}$ & $\begin{array}{l}-0.993 \\
(0.064)\end{array}$ & $\begin{array}{l}-1.11 \\
(10.8)\end{array}$ & 0.116 \\
\hline $\begin{array}{l}1981: 7- \\
1990: 6\end{array}$ & $\begin{array}{l}.00104 \\
(.00205)\end{array}$ & $\begin{array}{l}.0234 \\
(.0465)\end{array}$ & $\begin{array}{c}0.914 \\
(0.482\rangle\end{array}$ & $\begin{array}{l}-0.978 \\
(0.431)\end{array}$ & $\begin{array}{r}-16.42 \\
(54.6)\end{array}$ & 0.881 \\
\hline $\begin{array}{l}1975: 1- \\
1984: 12\end{array}$ & $\begin{array}{l}-.00057 \\
(.00438)\end{array}$ & $\begin{array}{l}.0124 \\
(.0122)\end{array}$ & $\begin{array}{c}0.938 \\
(0.369)\end{array}$ & $\begin{array}{l}-0.996 \\
(0.083)\end{array}$ & $\begin{array}{l}-5.95 \\
(22.1)\end{array}$ & 0.603 \\
\hline $\begin{array}{l}1985: 1- \\
1990: 6\end{array}$ & $\begin{array}{l}.00192 \\
(.00223)\end{array}$ & $\begin{array}{l}.0228 \\
(.0300)\end{array}$ & $\begin{array}{c}0.901 \\
(0.513)\end{array}$ & $\begin{array}{l}-0.940 \\
(0.450)\end{array}$ & $\begin{array}{r}-12.35 \\
(22.8)\end{array}$ & 0.157 \\
\hline \multicolumn{7}{|c|}{ Restrictions: $\phi^{d}=0, \phi^{b}=0, \phi^{s}=0$} \\
\hline Sample & Paramet & er estima & :es & & & Test of \\
\hline period & $\alpha$ & $\beta$ & $\gamma^{d}$ & $\gamma^{b}$ & $\gamma^{n}$ & OIR (p-value) \\
\hline $\begin{array}{l}1975: 1- \\
1990: 6\end{array}$ & $\begin{array}{l}.00884 \\
(.00304)\end{array}$ & $\begin{array}{l}0.128 \\
(0.021)\end{array}$ & $\begin{array}{l}2.14 \\
(3.98)\end{array}$ & $\begin{array}{l}3.23 \\
(1.63)\end{array}$ & $\begin{array}{l}-0.77 \\
(0.68)\end{array}$ & 0.000 \\
\hline $\begin{array}{l}1975: 1- \\
1981: 6\end{array}$ & $-.00141)$ & $\begin{array}{l}0.185 \\
(0.036)\end{array}$ & $\begin{array}{l}-8.56 \\
(2.35)\end{array}$ & $\begin{array}{l}0.63 \\
(0.17)\end{array}$ & $\begin{array}{l}-0.41 \\
(0.55)\end{array}$ & 0.000 \\
\hline $\begin{array}{l}1981: 7- \\
1990: 6\end{array}$ & $(.00946$ & $\begin{array}{c}0.131 \\
(0.035)\end{array}$ & $\begin{array}{c}9.25 \\
(7.24)\end{array}$ & $\begin{array}{l}-0.55 \\
(3.70)\end{array}$ & $\begin{array}{l}-1.46 \\
(1.15)\end{array}$ & 0.128 \\
\hline $\begin{array}{l}1975: 1- \\
1984: 12\end{array}$ & $\begin{array}{c}-.00180 \\
(.00071)\end{array}$ & $\begin{array}{c}0.229 \\
(0.068)\end{array}$ & $\begin{array}{l}-8.87 \\
(3.22)\end{array}$ & $\begin{array}{c}0.44 \\
(0.17)\end{array}$ & $\begin{array}{l}-0.19 \\
(0.67)\end{array}$ & 0.000 \\
\hline $\begin{array}{l}1985: 1- \\
1990: 6\end{array}$ & $\begin{array}{l}.00440 \\
(.00290)\end{array}$ & $\begin{array}{c}0.089 \\
(0.022)\end{array}$ & $\begin{array}{l}-1.97 \\
(5.70)\end{array}$ & $\begin{array}{c}0.81 \\
(1.15)\end{array}$ & $\begin{array}{l}-3.07 \\
(2.07)\end{array}$ & 0.638 \\
\hline
\end{tabular}


Table 2. (continued)

\begin{tabular}{|c|c|c|c|c|c|c|c|}
\hline \multirow{2}{*}{$\begin{array}{l}\text { Sample } \\
\text { period }\end{array}$} & \multicolumn{5}{|c|}{ Parameter estimates } & \multicolumn{2}{|c|}{ Test of } \\
\hline & $\alpha$ & $\beta$ & $\phi^{d}$ & $\phi^{b}$ & $\phi^{s}$ & OID & (p-value) \\
\hline $\begin{array}{l}1975: 1- \\
1990: 6\end{array}$ & $\begin{array}{l}.00635 \\
(.00369)\end{array}$ & $\begin{array}{l}.0075 \\
(.0074)\end{array}$ & $\begin{array}{c}0.561 \\
(0.541)\end{array}$ & $\begin{array}{l}-1.044 \\
(0.024)\end{array}$ & $\begin{array}{c}-0.001 \\
(0.003)\end{array}$ & & 0.456 \\
\hline $\begin{array}{l}1975: 1- \\
1981: 6\end{array}$ & $\begin{array}{c}.04477 \\
(.06793)\end{array}$ & $\begin{array}{l}.0105 \\
(.0026)\end{array}$ & $\begin{array}{l}-0.152 \\
(0.098)\end{array}$ & $\begin{array}{l}-1.028 \\
(0.018)\end{array}$ & $\begin{array}{c}0.005 \\
(0.003)\end{array}$ & & 0.354 \\
\hline $\begin{array}{l}1981: 7- \\
1990: 6\end{array}$ & $\begin{array}{c}.00330 \\
(.00213)\end{array}$ & $\begin{array}{l}.0247 \\
(.0200)\end{array}$ & $\begin{array}{c}0.706 \\
(0.511)\end{array}$ & $\begin{array}{l}-0.988 \\
(0.166)\end{array}$ & $\begin{array}{l}-0.006 \\
(0.006)\end{array}$ & & 0.460 \\
\hline $\begin{array}{l}1975: 1- \\
1984: 12\end{array}$ & $\begin{array}{c}.00792 \\
(.00496)\end{array}$ & $\begin{array}{l}.0061 \\
(.0063)\end{array}$ & $\begin{array}{c}0.448 \\
(0.559)\end{array}$ & $\begin{array}{l}-1.046 \\
(0.021)\end{array}$ & $\begin{array}{c}0.000 \\
(0.003)\end{array}$ & & 0.925 \\
\hline $\begin{array}{l}1985: 1- \\
1990: 6\end{array}$ & $\begin{array}{l}.00476 \\
(.00198)\end{array}$ & $\begin{array}{l}.1095 \\
(.0531)\end{array}$ & $\begin{array}{c}0.114 \\
(0.534)\end{array}$ & $\begin{array}{c}0.057 \\
(0.216)\end{array}$ & $\begin{array}{l}-0.024 \\
(0.011)\end{array}$ & & 0.423 \\
\hline
\end{tabular}

Notes: Estimates are for three models of Bundesbank operating procedures, described in the text. Estimates for subsamples are based on residuals estimated for a single VAR over the entire 1975-1990 sample period. Twelve lags of each variables are included in the VAR. The final column gives the p-value for the test of the overidentifying restrictions of the model for each subperiod. Standard errors are in parentheses. 
Table 3. German money growth and inflation targets, 1975-1995: Derivation and outcomes

\begin{tabular}{|c|c|c|c|c|c|c|c|c|}
\hline \multirow[b]{2}{*}{ Year } & \multicolumn{3}{|c|}{ MONEY GROWTH } & \multicolumn{3}{|c|}{ INFLATION } & \multirow{2}{*}{$\begin{array}{l}\text { POTENTIAL } \\
\text { OUTPUT } \\
\text { Projection }\end{array}$} & \multirow{2}{*}{$\begin{array}{l}\text { VELOCITY } \\
\text { Projection }\end{array}$} \\
\hline & Target & Actual & Deviation & Target & Actual & Deviation & & \\
\hline 1975 & 8 & 10.1 & +2.1 & 4.5 & 5.6 & +1.1 & NA & NA \\
\hline 1976 & 8 & 9.2 & +1.2 & 4.5 & 3.7 & -0.8 & $4.5 * \star$ & 0.5 \\
\hline 1977 & 8 & 9.0 & +1.0 & 4.0 & 3.3 & -0.7 & $5.0 \div$ & 1.0 \\
\hline 1978 & 8 & 11.4 & +3.4 & 3.5 & 2.6 & -0.9 & 3.0 & NA \\
\hline 1979 & $6-9$ & 6.1 & {$[-1.4]$} & 3.0 & 5.4 & +2.4 & 3.0 & NA \\
\hline 1980 & $5-8$ & 4.9 & -1.6 & 4.0 & 5.3 & +1.3 & 3.0 & 1.0 \\
\hline 1981 & $4-7$ & 3.5 & -2.0 & $3.5-4.0$ & 6.7 & +2.95 & 2.5 & 1.0 \\
\hline 1982 & $4-7$ & 6.0 & {$[+0,5]$} & 3.5 & 4.5 & +1.0 & $1.5-2.0$ & 0.0 \\
\hline 1983 & $4-7$ & 7.0 & {$[+1,5]$} & 3.5 & 2.6 & -0.9 & $1.5-2.0$ & 0.0 \\
\hline 1984 & $4-6$ & 4.6 & {$[-0.4]$} & 3.0 & 2.0 & -1.0 & 2.0 & 0.0 \\
\hline 1985 & $3-5$ & 4.5 & {$[+0.5]$} & 2.5 & 1.6 & -0.9 & 2.0 & 0.0 \\
\hline 1996 & $3.5-5.5$ & 7.7 & +3.2 & 2.0 & -1.0 & -3.0 & 2.5 & 0.0 \\
\hline 1987 & $3-6$ & 8.1 & +3.6 & 2.0 & 1.0 & -1.0 & 2.5 & 0.0 \\
\hline 1988 & $3-6$ & 6.7 & +2.2 & 2.0 & 1.9 & -0.1 & 2.0 & -0.5 \\
\hline 1989 & 5 & 4.7 & -0.3 & 2.0 & 3.0 & +1.0 & $2.0-2.5$ & -0.5 \\
\hline 1990 & $4-6$ & 5.6 & {$[+0.6]$} & 2.0 & 2.7 & +0.7 & 2.5 & -0.5 \\
\hline 1991 & $4-6 *$ & 5.2 & {$[+0.2]$} & 2.0 & 4.2 & +2.2 & 2.5 & -0.5 \\
\hline 1992 & $3.5-5.5$ & 9.4 & +4.9 & 2.0 & 3.7 & +1.7 & 2.75 & -0.5 \\
\hline 1993 & $4.5-6.5$ & 7.4 & +1.9 & 2.0 & 3.7 & +1.7 & 3.0 & $-1.0 \pm \star \star$ \\
\hline 1994 & $4-6$ & 5.7 & {$[+0.7]$} & 2.0 & 2.5 & +0.5 & 2.5 & -1.0 \\
\hline 1995 & $4-6$ & 2.1 & -2.9 & 2.0 & 1.8 & -0.2 & 2.75 & -1.0 \\
\hline
\end{tabular}

Notes: "Money" is central bank money at 1974 reserve ratios through 1987, West German M3 for 1988-1990, and all-German M3 since 1991. Money growth rates are measured year over year for 1975-1978 and fourth quarter to fourth quarter thereafter. Deviations are measured from the midpoint of the target range; brackets indicate that the money-growth outcome was within the target range. For 1975-1985, inflation targets are the announced rate of "unavoidable inflation". Since 1986, the inflation target has been 2.08 , the rate judged consistent with "price stability". Money growth targets are calculated (using the quantity equation) as the inflation target plus the potential growth of production minus an adjustment for expected changes in velocity.

* The 1991 target range for money growth was lowered to 3-58 in July. ** Includes expected increase in capacity utilization as well as increase in production potential.

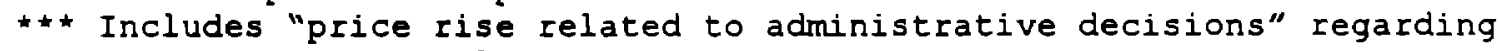
eastern Germany as well as velocity adjustment.

Source: Deutsche Bundesbank, Monthly Reports and Annual Reports, various issues. 
Table 4. Determinants of German monetary policy

\begin{tabular}{|c|c|c|c|c|}
\hline \multirow{2}{*}{\multicolumn{2}{|c|}{ Variables }} & \multicolumn{3}{|c|}{ (p-value) } \\
\hline & & Lombard rate & Call rate & $\mathrm{LR} / \mathrm{CR}$ \\
\hline 1 . & $\begin{array}{l}E_{t}\left(C P I_{t+12}-C P I_{t}\right) \\
E_{t}\left(M_{t+12}-M_{t}\right) \\
\text { Policy indicator }\end{array}$ & $\begin{array}{l}.0296 \\
.0387 \\
.0000\end{array}$ & $\begin{array}{l}.0176 \\
.1298 \\
.0000\end{array}$ & $\begin{array}{l}.0221 \\
.0548 \\
.0000\end{array}$ \\
\hline 2 . & $\begin{array}{l}E_{t}\left(C P I_{t+12}-C P I_{t}\right) \\
E_{t}\left(I P_{t+12}-I P_{t}\right) \\
E_{t}\left(M_{t+12}-M_{t}\right) \\
\text { Policy indicator }\end{array}$ & $\begin{array}{l}.0351 \\
.0751 \\
.0498 \\
.0000\end{array}$ & $\begin{array}{l}.0443 \\
.5226 \\
.1132 \\
.0000\end{array}$ & $\begin{array}{l}.0209 \\
.1660 \\
.1024 \\
.0000\end{array}$ \\
\hline 3. & $\begin{array}{l}E_{t}\left(C P I_{t+12}-C P I_{t}\right) \\
E_{t}\left(I P_{t+12}-I P_{t}\right) \\
E_{t}\left(M_{t+12}-M_{t}\right) \\
\text { Policy indicator } \\
E_{t}\left(E R_{t+12}-E R_{t}\right)\end{array}$ & $\begin{array}{l}.0236 \\
.4175 \\
.0258 \\
.0000 \\
.3742\end{array}$ & $\begin{array}{l}.0287 \\
.5968 \\
.1012 \\
.0000 \\
.4385\end{array}$ & $\begin{array}{l}.0963 \\
.6134 \\
.2670 \\
.0000 \\
.9543\end{array}$ \\
\hline
\end{tabular}

\section{Percentage of Lombard rate forecast variance (horizon in months)}

\begin{tabular}{|c|c|c|c|c|c|c|c|c|}
\hline & on Variables & 1 & 2 & 3 & 4 & 6 & 12 & 24 \\
\hline 1 & $\begin{array}{l}E_{t}\left(C P I_{t+12}-C P I_{t}\right) \\
E_{t}\left(M_{t+12}-M_{t}\right) \\
\text { Lombard rate }\end{array}$ & $\begin{array}{r}3.4 \\
0.0 \\
96.5\end{array}$ & $\begin{array}{r}1.7 \\
0.6 \\
97.7\end{array}$ & $\begin{array}{r}1.1 \\
0.7 \\
98.2\end{array}$ & $\begin{array}{r}0.8 \\
0.9 \\
98.3\end{array}$ & $\begin{array}{r}3.4 \\
2.1 \\
94.5\end{array}$ & $\begin{array}{r}18.0 \\
1.8 \\
80.2\end{array}$ & $\begin{array}{r}58.2 \\
2.5 \\
39.3\end{array}$ \\
\hline 2 & $\begin{array}{l}E_{t}\left(C P I_{t+12}-C P I_{t}\right) \\
E_{t}\left(I P_{t+12}-I P_{t}\right) \\
E_{t}\left(M_{t+12}-M_{t}\right) \\
\text { Lombard rate }\end{array}$ & $\begin{array}{r}3.7 \\
0.1 \\
0.7 \\
95.6\end{array}$ & $\begin{array}{r}2.1 \\
1.0 \\
0.7 \\
96.2\end{array}$ & $\begin{array}{r}2.2 \\
3.8 \\
0.8 \\
93.2\end{array}$ & $\begin{array}{r}2.5 \\
8.0 \\
1.2 \\
88.3\end{array}$ & $\begin{array}{r}9.1 \\
14.2 \\
3.8 \\
72.8\end{array}$ & $\begin{array}{r}31.5 \\
17.9 \\
5.7 \\
44.9\end{array}$ & $\begin{array}{r}61.8 \\
10.7 \\
6.7 \\
20.9\end{array}$ \\
\hline & $\begin{array}{l}E_{t}\left(C P I_{t+12}-C P I_{t}\right) \\
E_{t}\left(I P_{t+12}-I P_{t}\right) \\
E_{t}\left(M_{t+12}-M_{t}\right) \\
\text { Lombard rate } \\
E_{t}\left(E R_{t+12}-E R_{t}\right)\end{array}$ & $\begin{array}{r}0.3 \\
0.0 \\
0.6 \\
99.0 \\
0.0\end{array}$ & $\begin{array}{r}1.0 \\
0.6 \\
0.6 \\
95.0 \\
2.7\end{array}$ & $\begin{array}{r}3.1 \\
2.4 \\
0.6 \\
91.8 \\
2.0\end{array}$ & $\begin{array}{r}5.0 \\
5.3 \\
0.7 \\
87.5 \\
1.5\end{array}$ & $\begin{array}{r}14.4 \\
10.3 \\
2.2 \\
72.2 \\
0.9\end{array}$ & $\begin{array}{r}36.3 \\
11.0 \\
2.5 \\
43.4 \\
6.9\end{array}$ & $\begin{array}{r}47.7 \\
9.2 \\
3.4 \\
21.1 \\
18.6\end{array}$ \\
\hline
\end{tabular}

Notes: This table is derived from three-, four-, and five-variable VARs including combinations of the policy indicator (the Lombard rate, the call rate, or a splice of the two rates); and twelve-month-ahead VARbased forecasts of the growth rates of the CPI, industrial production, the money stock (CBM through 1987, M3 afterwards), and the DM/\$ exchange rate. The top half of the table gives $p$-values for tests of whether each variable Granger-causes the alternative policy indicators, with low values indicating a significant relationship. The bottom half of the table shows decompositions of forecast variance at various horizons for the Lombard rate only. 


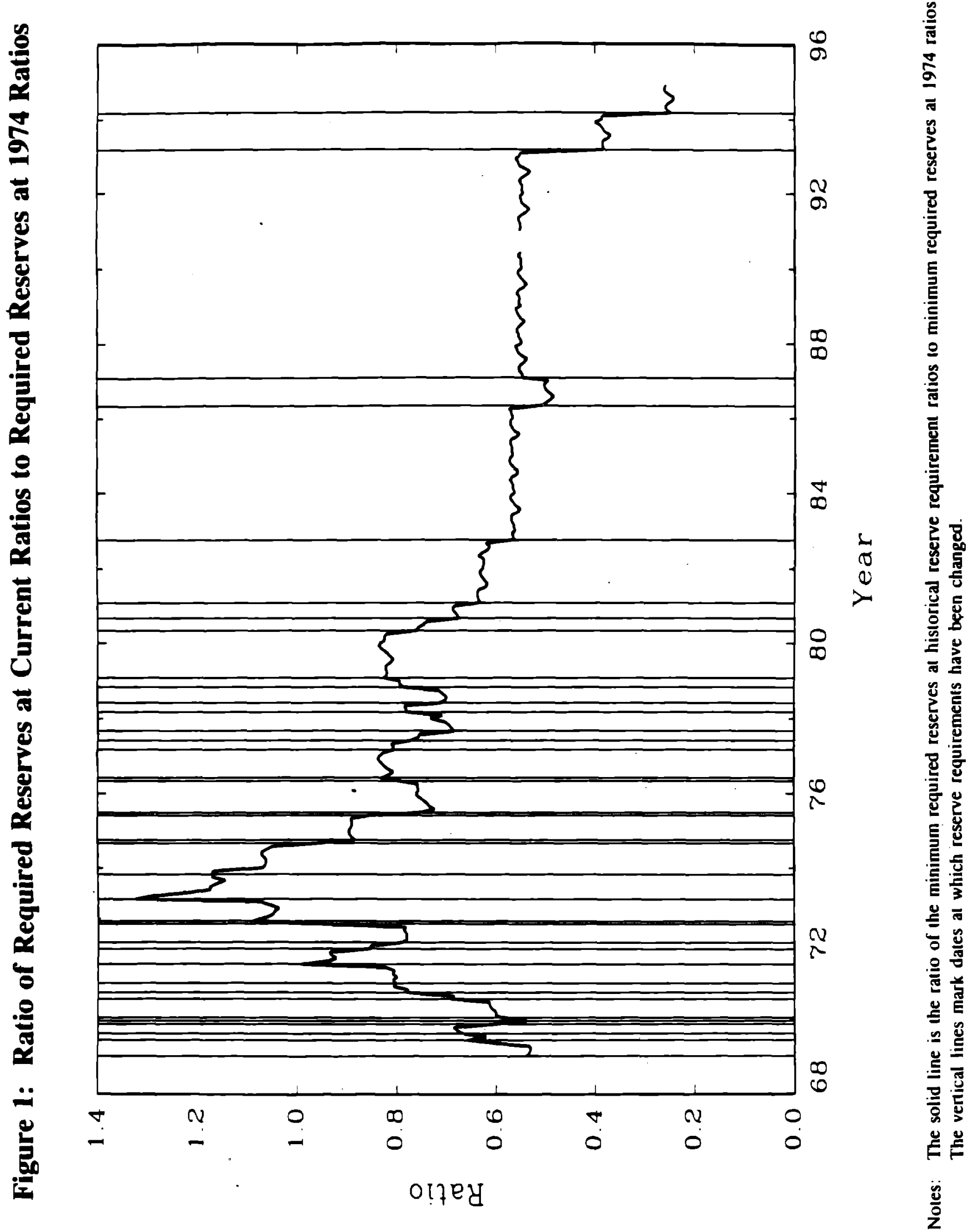


Figure 2: Responses of Output, Prices, and Interest Rates to Call Rate and Lombard Rate Shocks in Two Vector Autoregressions

Call ?ate Yodel Response of IP

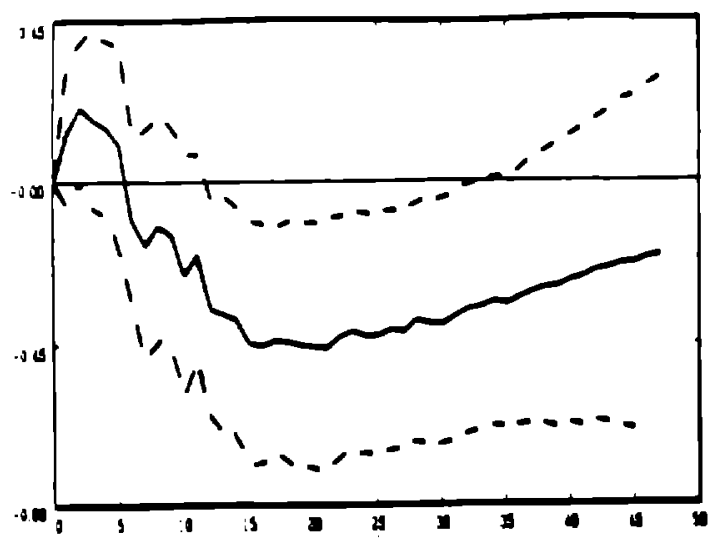

Cail Tate Yodel. Response of CPI

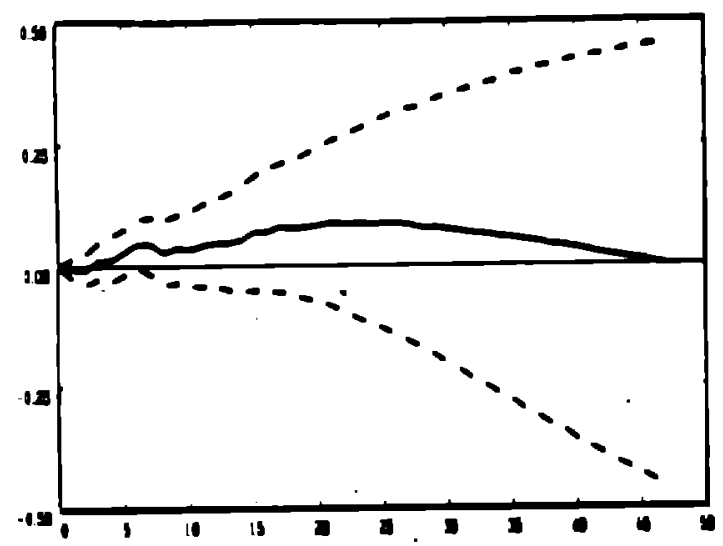

Call Rate Yodel: Reaponse of Call Rate

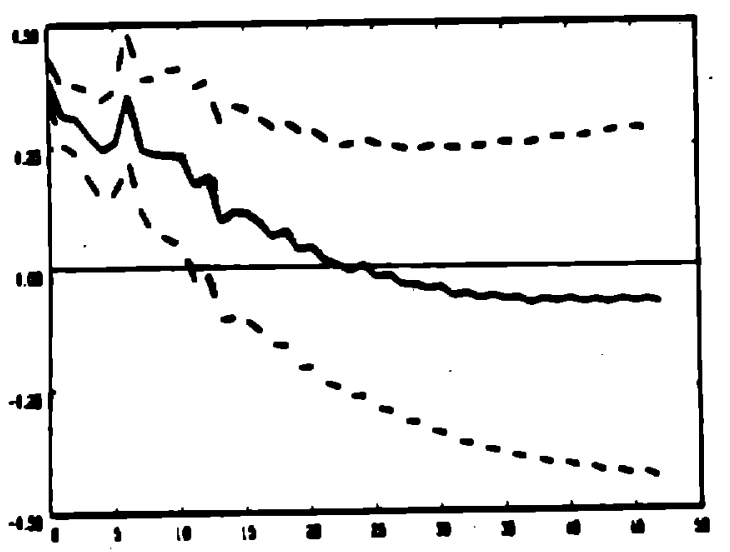

Lombard Rale Yodel Response of IP

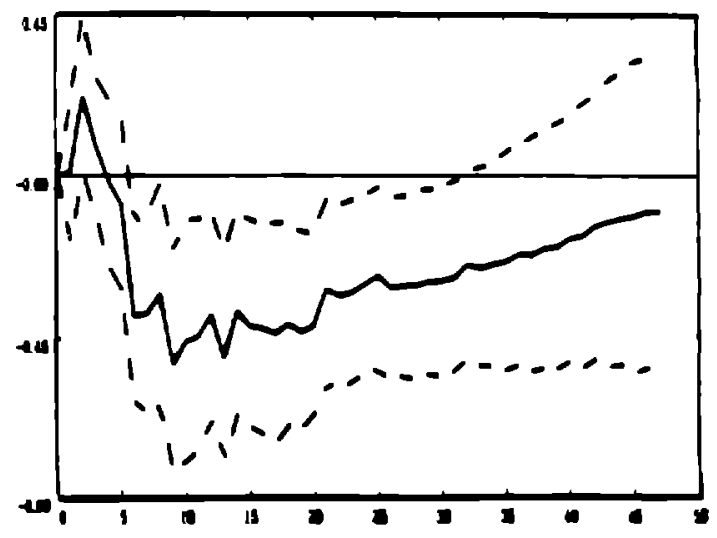

Lombard Rale Model: Response of CPI

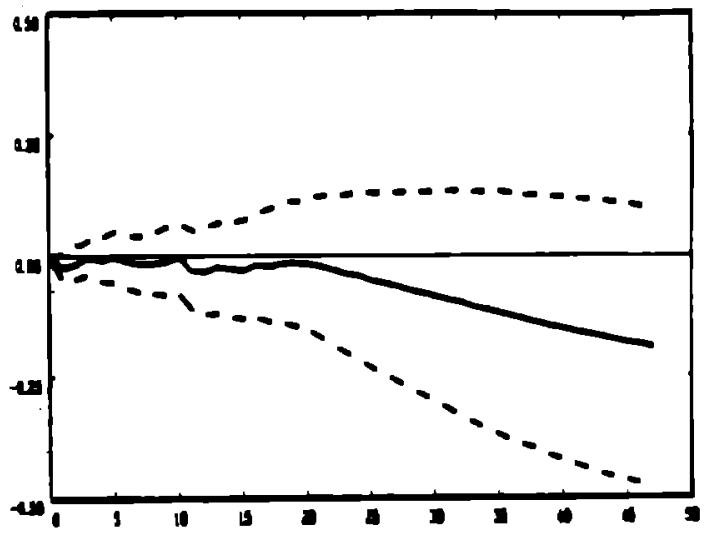

Lombard Rate Yodel: Respouse of Lombard Rate

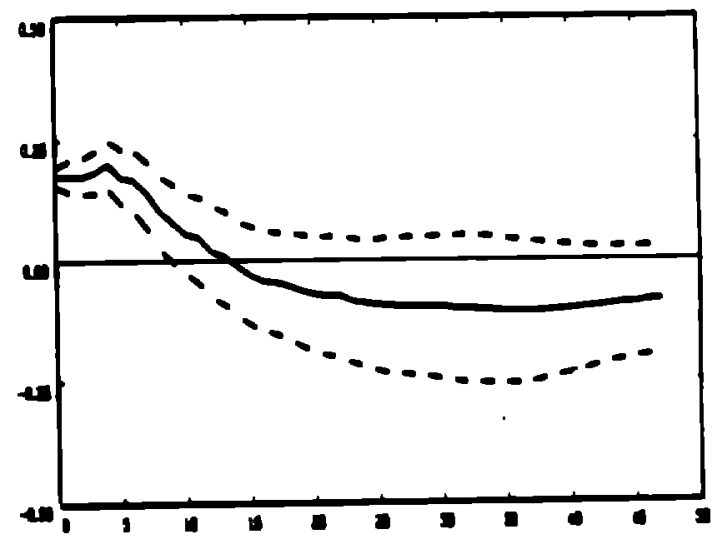

Nores: The first columa presents impule responses after a one-sonderd deviation shock w the call rite. These reoponses are based on eximeces trom a four-variable monthly VAR with IP, CPI, commodity price inder, and the call rute The second column presents impulse responses after a one-sandard deviation shock to the Lomberd rese. These resonses are based on eximases from a fourvarible monthly VAR with IP, CPL, commodity price inder, and the Lomberd rate. Twelve lars of each variable are included in both VARs. The dacbed lines mark 95\% confidence intervale The sample is 1975:1 - 1990:6. 
Figure 3: Responses of the Lombard Rate and Forecasts of Inflation, Output Growth, Yoney Growth, and Exchange Rate Depreciation to an Innovation in the One-Year Forecast of Inflation

Response of Inflatuon Forecast

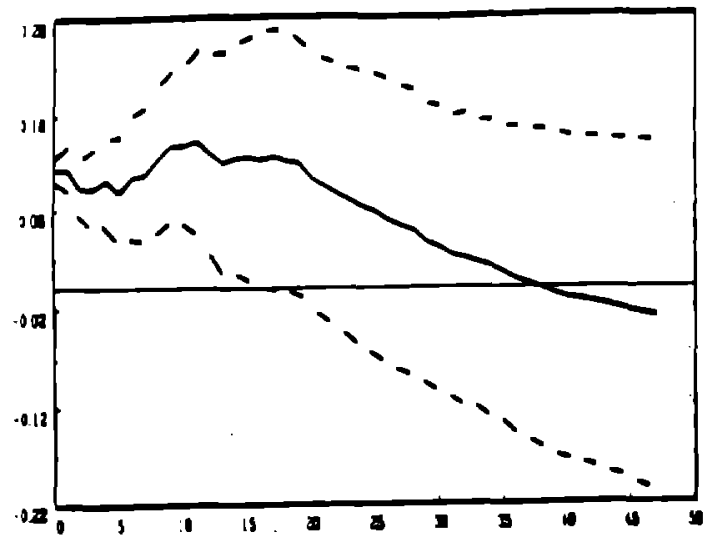

Response of Yoney Growth Forecast

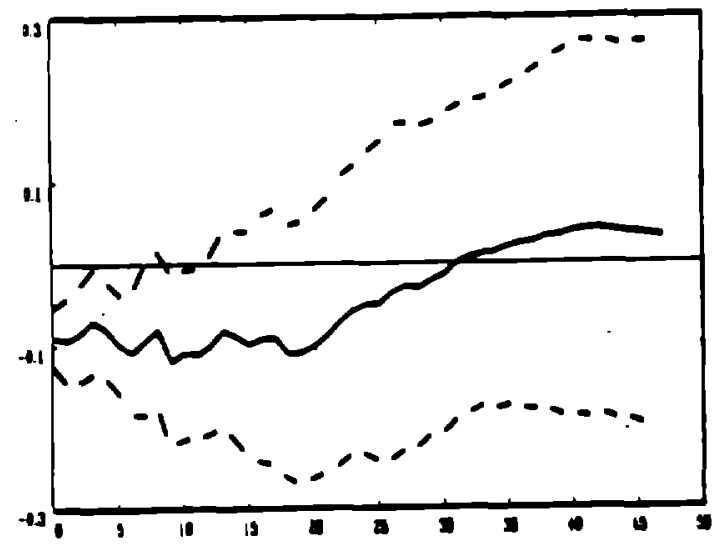

Response of Output Growth Porecast

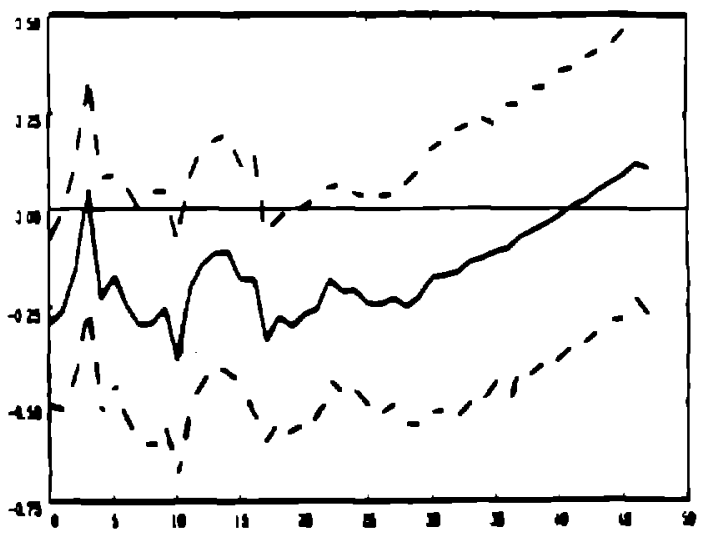

Response of Exchange Rate Depreciation Porecast

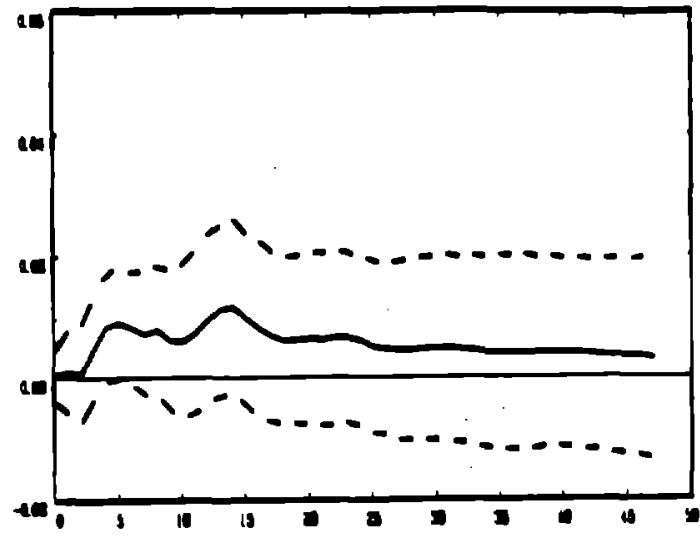

Response of Lombard Rate

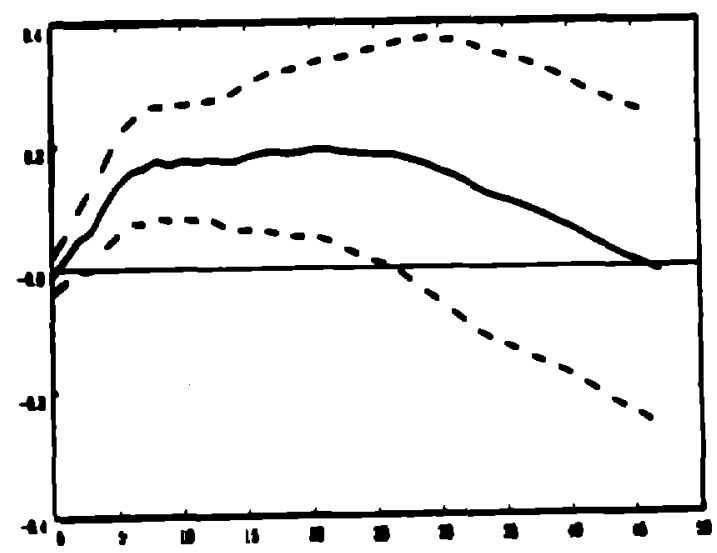

Votes: The figure presents impulse responses after a one-standard deviation shock to the inflation forecase These responses are Vase based on estimales frecasts are derived from a six-variable VAR deccribed in the tex the dashed lines mart $95 \%$ confidence in the picure. The forecasts are derived from 